يسهم التعليم الصناعى بنصيب وافر فى دفع عجلة الإنتاج والتقدم الاقتصادى ، وتحقيق التتمية فى المجتمعات المختلفة ؛ إذ تسند إليه مهمة إعداد العنصر البشرى القادر على التعامل مع معطيات العصر المختلفة ، وقيادة التتمية ومن أهداف التعليم الصناعى إعداد العامل الفنى الماهر القادر على القيام بالنشاطات المطلوبة فى المجالات الصناعية التى تسهم فى دفع تتمية الاقتصاد ،

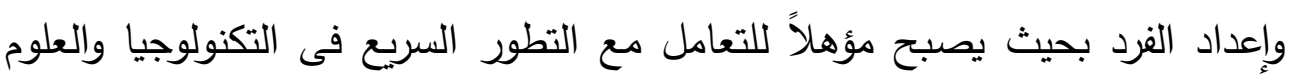
التقنية .

لذلك يعتبر التعليم صناعى فى أى من دول العالم هو المصدر الرئيسى لإمداد سوق العمل بالعمالة الفنية المدربة حرفيا، والتى تلعب دورا هاما فى تتمية البلاد ، لهذا يحظى هذا النوع من التعليم بأهمية كبرى فى معظم دول العالم المتقدم .

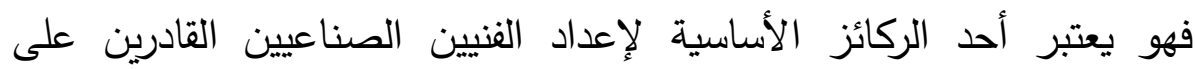

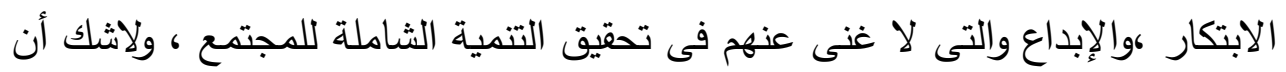
التوسع فى التعليم الفنى الصناعى دون توفير معلم معد إعدادا جيدا قد أدى إلى هبوط هذا النوع من التعليم وضعف مستوى خريجيه ، ولازالت الهوة واسعة بين الخبرة

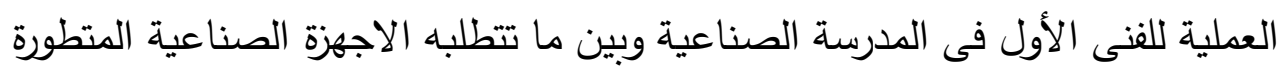

$$
\text { فى المؤسسات والشركات الصناعية }
$$

ويشهد العالم اليوم ثورة علمية وتكنولوجية كبيرة لم تحدث من قبل , حيث النمو

المتزايد والسريع فى حجم وكمية المعلومات فى جميع حقول المعرفة, ويمكن القول ان حجم المعلومات المنتجة فى العصور الثلاثة الماضية يفوق حجم المعلومات التى انتجتها البشرية خلال العصور السابقة حيث ان حجم هذه المعلومات يتضاعف كل ع او 0 سنوات, ويلاحظ على سبيل المثال ان حجم المعلومات فى عام ب999 ام كانت

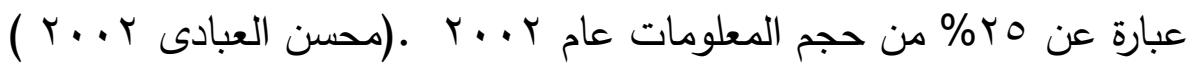


تصميم برنامج إثرائى قائم على المعامل الافتراضية لتنمية مهارات أ.سماح محمد ناجى

من اهم سمات الثورة المعلوماتية النمو التقنى الهائل الذى نجم عنه شبكات معلومات سريعة تحمل فى طياتها احتمال تغيير ما يجرى فى النظم الدراسية, ومن هنا اصبح على هذه النظم ان تعد الانسان لعصر المعلوماتية , وذلك بتزويده بالمعارف وبالمهارات الجديدة واصبح المطلب الذى ينبغى ان تسعى اليه ليس مجرد

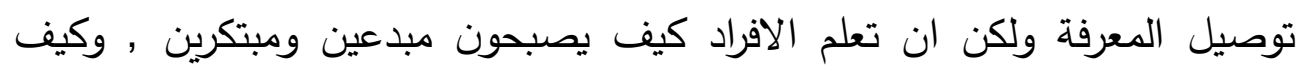
يستخدمون التقنيات الجديدة والمعلومات من مصادرها المتنوعة لتتشيط افكارهم بشكل

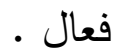

فكان لابد من الدمج بين هذه الثورة العلمية التكنولوجية والتعليم بحيث تتداخل تكنولوجيا التعليم والمستحدثات الحديثة فى جميع المراحل التعليمة بشكل عام والتعليم

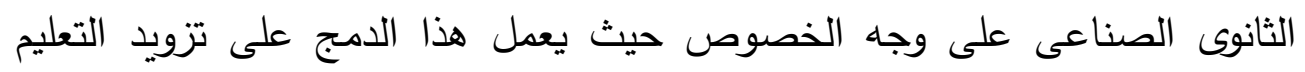

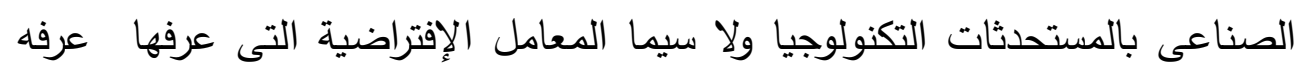

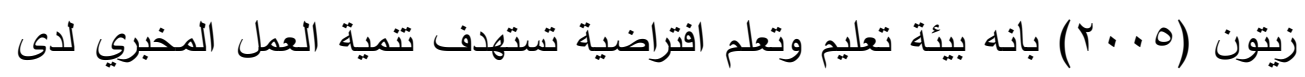

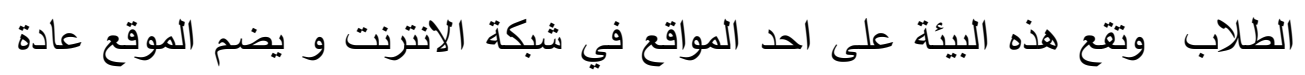

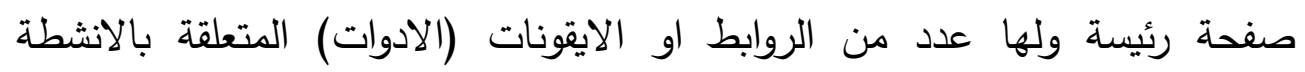
المختبرية و انجازاتها و تقويمها (حسن زيتون,0 . . ب). حيث تقوم المعامل الافتراضية على التجريب وخلق مواقف تعليمية تمثل العالم

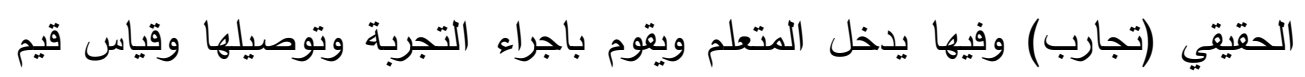

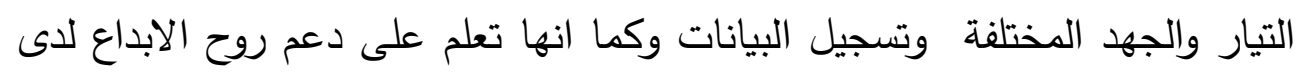
المتعلم ومن خلال هذه البيئة الافتراضية يمكن ان يصبح مخترعاً

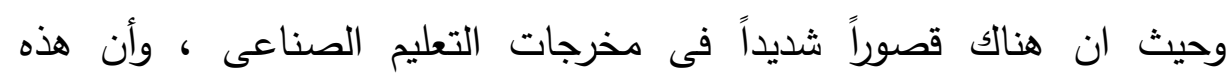

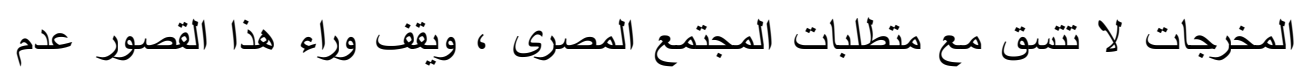

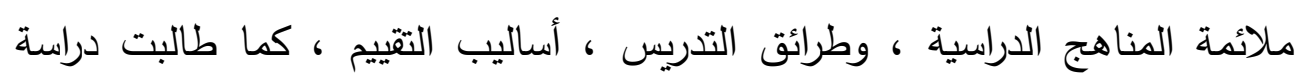

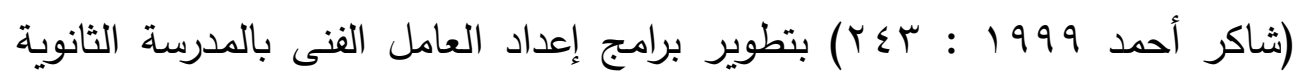


الصناعية ؛ بحيث يلبى المتطلبات الآتية والمستقبلية ، ويحقق توافق الإعداد للحياة العملية .

وخريجو التعليم الصناعى ليسوا بالكفاءة التى تمكنهم من التكيف مع طبيعة الحرف والمهن التى تتصف بالتغير السريع ، ولذا يجب مراجعة محتوى برامج التعليم الصناعى ؛ لأنها مسئولة بشكل مباشر فى ضعف قدرات المتعلمين على اكتساب المهارات الفنية اللازمة للعمل فى المجالات الإنتاجية بسوق العمل المنتج (عادل صادق r.. (199-191: وأرجع عدد من الباحثين والهيئات المتخصصة - ومنها هيئة اليونسكو - هذا الأمر إلى عدة عوامل منها قصور برامج إعداد العامل الفنى بالتعليم الصناعى ، خاصة المقررات الثقافية والفنية فهى ليست هادفة ، وهى مجرد قنوات للعبور من

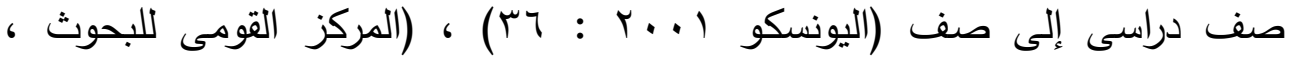

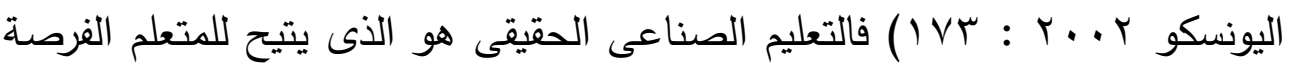
لاكتساب المعارف والمهارات التى تؤهله لممارسة العمل المنتج داخل بيئته . وايضاً اذا نظرنا الى مادة الاساسيات الكهربية وما بها من جزء معملى مهم لهمه خاص بتدريب الطلاب على كيفية تكوين دائرة كهربية واكتساب مهارة توصيل العناصر الاككترونية معا بحرفية توصيلا عمليا صحيحاً فهى تحتاج الى اكتساب مهارة التدريب والتجريب الدائم بحيث يكون خريجى المدارس الصناعية من الكفاءة والمهنية والحرفية التى تؤهله لمواجه متطلبات سوق العمل .وهذا ما يقوم به المعمل الافتراضى حيث يعطى المتعلم الفرصة للتدريب والتجريب ودون تعرضه للمخاطر التى تهدد حياته .

وحيث أن الكثير من الأساليب و الأدوات المستخدمة في المختبر التقليدي لم تعد تفي بحاجة المتعلمين لاسباب عديدة, لذا ظهرت الحاجة إلى تفعيل و استغلال أحدث تقنيات العصر للوصول إلى تعلم و تعليم فعال وذلك من خلال استخدام المستحدثات 194 
تصميم برنامج إثرائى قائم على المعامل الافتراضية لتنمية مهارات أ.سماح محمد ناجى

التكنولوجية و الاتصالات و استغلالها لتطوير تدريس مادة الاساسيات الكهربية

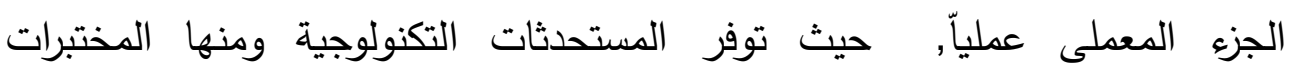
الافتراضية بيئة تعلمية تفاعلية نشطة آمنه تحاكي الواقع والتي تعد مكتبة من التناتئ

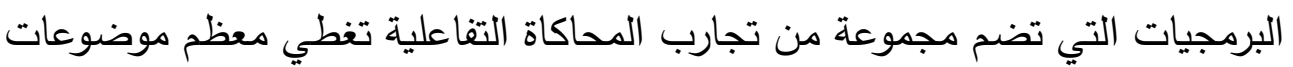

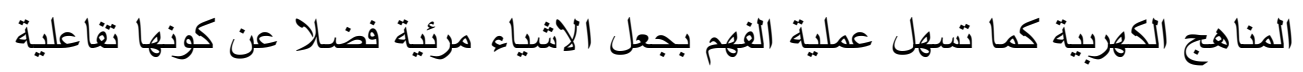

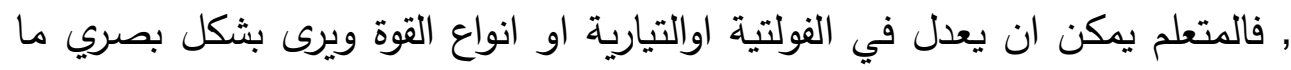

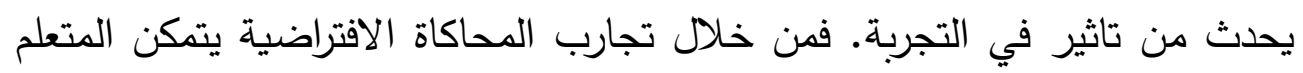
من تطوير قدراته و مهاراته الادراكية اذ تسمح له بالملاحظة العلمية الدقيقة و

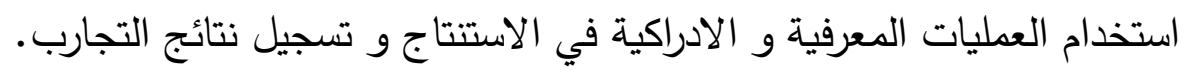

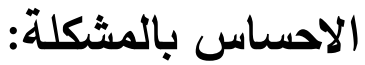

من خلال عمل الباحثة كمعلمة لمادة الاساسيات الكهربية شعبة تعليم صناعى تخصص الكترونيات بمدارس الثانوية الصناعية نظام ثلاث سنوات على مدار

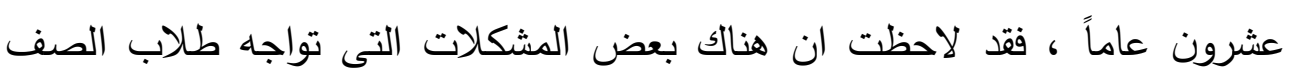

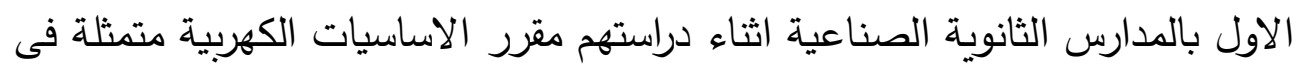
ضعف مهاراتهم فى تكوين الدوائر الالكترونية . وفى محاولة من الباحثة للتعرف على ابعاد المشكلة فقد تم عمل الاتى:

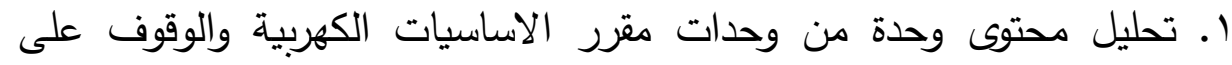
طبيعة المهارات المتضمنة لدحتوى المقرر ومدى قابليتها للتطبيق وفاعليتها فى تتمية المهارات لدى المتعلمين.

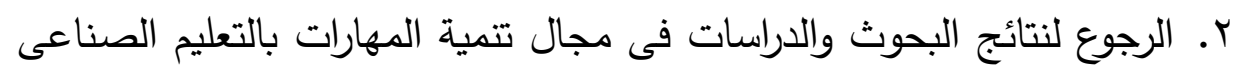

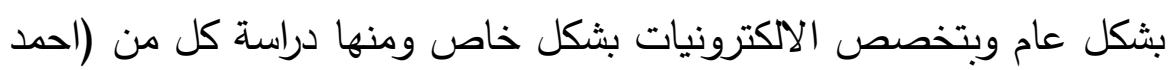

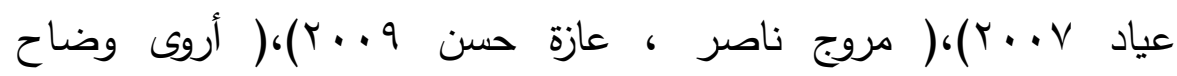

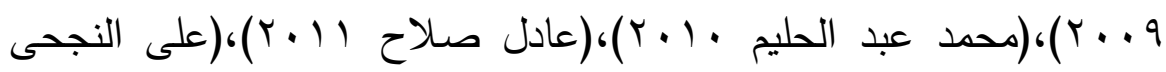




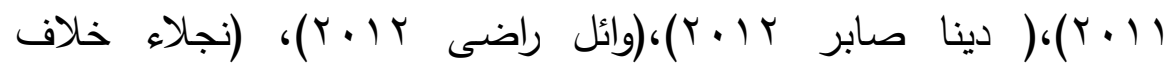

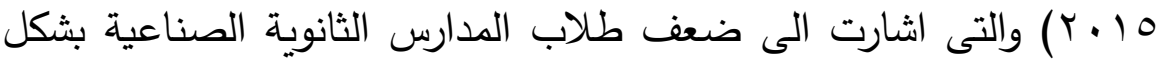
عام فى المهارات العملية واوصت بضرورة توفير بيئات تعتمد على توظيف تكنولوجيا الكمبيوتر بما يسهم فى تتمية تلك المهارات ويلائم مقرر اساسيات

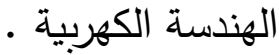
r. عمل لقاءات مفتوحة مع (·)عشرون من الخبراء فى مجال التعليم الصناعى من الموجهيين والمعلمين والقائمين بتدريس مقرر اساسيات الهندسة الكهربية ـ حيث اكد غالبيتهم الى ضعف مهارات تكوين الدوائر الالكترونية لطلاب المدارس الثانوية الصناعية بمقرر الاساسيات الكهربية. واشاروالى ان البيئات التعليمية التى تتناول موضوعات المقرر بيئات فقيرة ولا تسهم بشكل كبير فى تدريب الطلاب على اتقان مهارات تكوين الدوائر الالكترونية. ع. تم تصميم بطاقة ملاحظة الاداءات المهارية لدى طلاب المدارس الثانوية الصناعية تخصص الكترونيات فى مهارات تكوين الدوائر الالكترونية بمقرر الاساسيات الكهربية وقد تضمنت ثلاث مهارات رئيسية واشتملت كل مهارة رئيسية على مجموعة من المهارات الفرعية وتم تطبيق تلك البطاقة على عينة من الطلاب وصلت الى(Yo) خمسة وعشرون طالبة واشارت تطبيق الاستمارة الى ضعف الطالبات فى تكوين الدوائر الالكترونية.

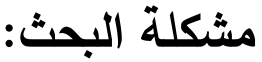

وتأسيسا على ماسبق فإن مشكلة البحث تتحدد فى ضعف مهارات طالبات المدرسة الثانوية الصناعية تخصص الكترونيات نظام السنوات الثلاث فى تكوين الدوائر الاككترونية بما يؤثر بالسلب على مخرجات العملية التعليمية ، ناتج عن نمطية بيئات التعليم والتذريب المستخدمة. 
تصميم برنامج إثرائى قائم على المعامل الافتراضية لتنمية مهارات أ.سماح محمد ناجى

\section{تساؤلات البحث:}

1. ما هى مهارات تكوين الدوائر الإكترونية التى يمكن تتميتها لدى طلاب

تخصص - الإكترونيات بالمدرسة الثانوية الصناعية.

r. كيف يمكن تتمية مهارات تكوين الدوائر الإككترونية لدى طلاب تخصص باله الإلكترونيات بالمدرسة الثانوية الصناعية.

r. ما التصميم المقترح لبرنامج إثرائى قائم على المعامل الإفتراضية لتنمية مهارات تكوين الدوائر الإكترونية لدى طلاب تخصص - الإلكترونيات بالمدرسة الثانوية الصناعية. ع. ما فاعلية ما التصميم المقترح لبرنامج إثرائى قائم على المعامل الإفتراضية لتتمية مهارات تكوين الدوائر الإلكترونية لدى طلاب تخصص الإلكترونيات بالمدرسة الثانوية الصناعية.

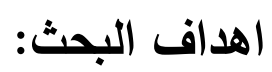

ا ـ تنمية مهارات طلاب المدرسة الثانوية الصناعية تخصص - الإلكترونيات فى تكوين الدوائر الإلكترونية.

r. الوقوف على مدى فعالية البيئات الإثرائية على المعامل الإفتراضية فى تتمية مهارات تكوين الدوائر الإلكترونية لدى طلاب تخصص - الإلكترونيات بالمدرسة الثانوية الصناعية.

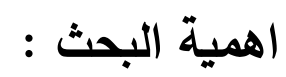

تتمثل اهمية البحث فيما يمكن ان تؤدى نتائجه الى ما يلى: ا ـ تصميم برنامج إثرائي قائم على المعامل الافتراضية بتخصص -الإلكترونيات بالمدرسة الثانوية الصناعية. 
r. المساهمة فى تحسين مخرجات العملية التعليمية بالمدرسة الثانوية الصناعية تخصص الكترونيات.

r. المساهمة فى امداد سوق العمل بعمالة فنية مدربة وماهرة فى الإلكترونيات. ـ. مسايرة الاتجاهات العالمية التى تنادى بتطبيق التعليم الإكتروني القائم على المعامل الإفتراضية.

\section{فروض البحث:}

فى ضوء ما تم دراسته من نقاط علمية ومحاور نظرية مرتبطة بطبيعة البحث وفى ضوء تساؤلاته يسعى البحث إلي التحقق من صحة الفروض التالية: ا. يوجد فرق ذو دلالة احصائية عند مستوى(1 +.,·) بين متوسطى درجتى طلاب المجموعة التجريبية والمجموعة الضابطة فى إختبار التحصيل المعرفى قبل وبعد تطبيق البرنامج الإثرائى القائع على المعامل الافتراضية لصالح طلاب المجموعة التجريبية فى الاختبار البعدى. r. يوجد فرق ذو دلالة احصائية عند مستوى(1, +.) بين متوسطى درجتى طلاب المجموعة التجريبية والمجموعة الضابط فى بطاقة ملاحظة الاداء المهارى قبل وبعد تطبيق البرنامج الإثرائى القائم على المعامل الافتراضية لصالح المجموعة التجريبية فى الاختبار البعدى. r. توجد علاقة ارتباطية موجبة بين متوسطى درجات طلاب المجموعة التجربية فى نمط التدريس القائم على المعامل الافتراضية بالبرنامج الإثرائى المقترح. ع. توجد علاقة ارتباطية موجبة بين متوسطى درجات طلاب المجموعة التجربيية فى نمط التدريس القائم على البرنامج الإثرائى بمقرر أساسيات الهندسة الكهربية وتتمية مهارات تكوين الدوائر الالكترونية. 
تصميم برنامج إثرائى قائم على المعامل الافتراضية لتنمية مهارات أ.سماح محمد ناجى

حدود البحث:

حدود بثرية: طلاب الصف الاول تخصص - الإلكترونيات.

حدود مكانية: مدرسة السيدة حنيفة السلحدار الثانوية الصناعية بنات.

حدود زمنية: تم تطبيق أدوات القياس وأدوات البحث التجريبية على مدار الفصل ملى مليده

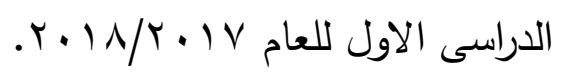

حدود موضوعية: مقرر اساسيات الهندسة الكهربية ، مهارات تكوين الدوائر الإلكترونية تخصص - إلكترونيات بالمدرسة الثانوية الصناعية.

متغيرات البحث:

المتغير المستقـل: البرنامج الاثرائى القائم على المعامل الافتراضية. المتغسير التابع : تتمية مهارات تكوين الدوائر الالكترونية بتخصص الإكترونيات بالمدرسة الثانوية الصناعية.

ادوات البحث : (1)

$$
\text { تتمثل ادوات البحث والقياس فى التالى : }
$$

1. اختبار تحصيل معرفى فى أساسيات الهندسة الكهربية (من اعداد الباحثة) r. بطاقة ملاحظة الاداءات المهارية فى تكوين الدوائر الالكترونية (من اعداد

$$
\text { الباحثة) }
$$

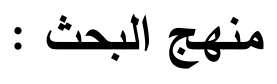

ا ـ المنهج الوصفى التحليلي:

حيث ان المنهج الوصفى هو "المنهج الذى يدرس ظاهرة او حدثاً او قضية موجودة حالياً يمكن الحصول منها على معلومات تجيب عن اسئلة البحث دون تدخل

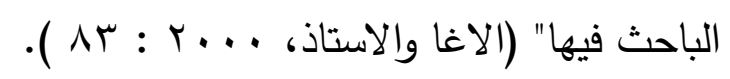


اما تحليل المحتوى فهو "اسلوب يستخدم اساليب اخرى لتقويم المناهج من اجل تطويرها وهو يعتمد على تحديد اهداف التحليل ووحدة التحليل للتوصل الى مدى شيوع ظاهرة او احد المفاهيم او فكرة او اكثر وبالتالى تكون نتائج هذه العملية الى جانب ما يتم الحصول عليه من نتائج من خلال اساليب اخرى مؤشرات تحدد اتجاه التطوير

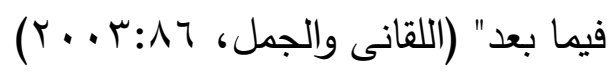
وهذا ما استخدمه البحث الحالى وذلك لتحديد أهداف البرنامج المقترح فى تتمية تكوين الدوائر الإكترونية، وبناء البرنامج فى ضوء تلك الأهداف، وايضًا إعداد قائمة بالمفاهيم والمهارات التى اشتمل عليها مقرر منهج اساسيات الهندسة الكهربية للصف الاول الثانوى الصناعى تخصص الكترونيات، كما تم الاستفادة من الادبيات والبحوث المرتبطة بمتغيرات البحث فى بناء بطاقة الملاحظة والاختبارات المعرفية. r. المنهج التجريبى: المنهج التجريبى هو "المنهج الذى يدرس ظاهرة حالية مع ادخال تغيرات فى احد العوامل او اكثر ورصد نتائج هذا التغير" (الاغا

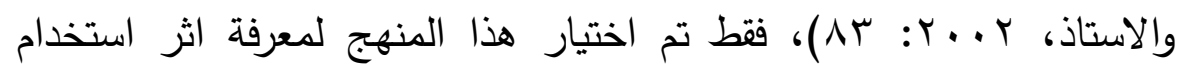
المعامل الافتراضية على تتمية مهارات تكوين الدوائر الالكترونية لدى طلاب الصف الاول الثانوى الصناعى بالمدرسة الثانوية الصناعية تخصص الإلكترونيات.

\section{مصطلحات البحث:}

البرامج الاثرائية :

هي خبرات تربوية تتسم بالتنوع والعمق العلمي والفكري والتي غالبا لا تتوفر في المنهج المدرسي العام. 
تصميم برنامج إثرائى قائم على المعامل الافتراضية لتنمية مهارات أ.سماح محمد ناجى

\section{المعامل الافتراضية}

يعرفها البلطان اس؟ ا هـ بأنها "معامل الكترونية يتم العمل فيها عن طريق

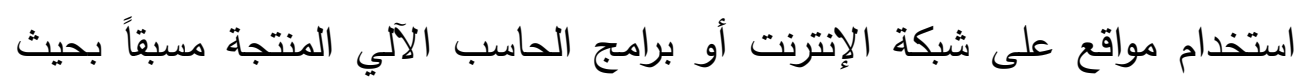
يستطيع الطالب محاكاة التجارب العلمية وتطبيقها كما هي في أرض الواقع دون

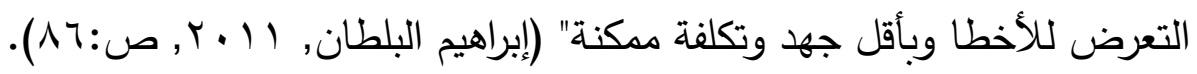
ويعرفها زيتون بانها بيئة تعليم وتعلم افتراضية تستهدف تتمية العمل المخبري لاى الطلاب وتقع هذه البيئة على احد المواقع في شبكة الانترنت و يضم الموقع عادة صفحة رئيسة ولها عدد من الروابط او الايقونات (الادوات) المتعلقة بالانشطة

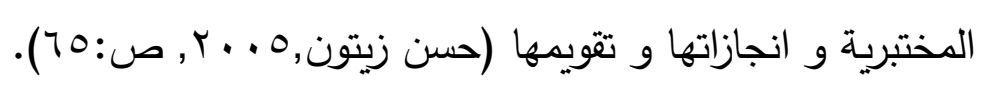

وتعرفها الباحثة إجرائياً بأنها "بيئة تعلم وتعليم إلكترونية إفتراضية تحاكى المعامل

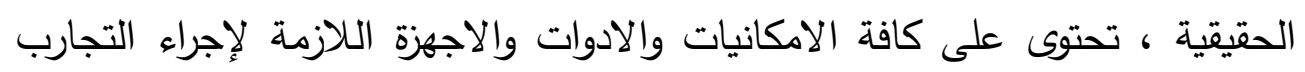
المعملية بعدد غير محدود من المرات ، وبشكل آمن دون التعرض لأى مخاطر تذكر الآليه

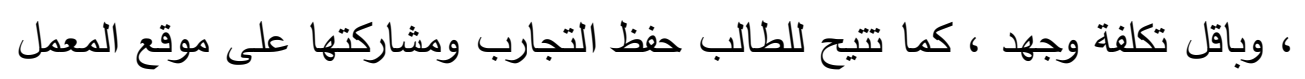

الإفتراضى.

\section{المهارة}

تعرف بانها قدرة المتعلم على تتفيذ أمر ما بدرجة إتقان مقبولة ويعنى بدرجة

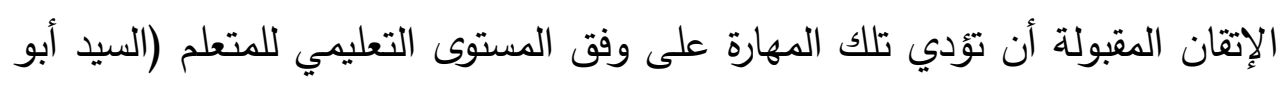

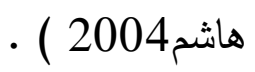

وتعرفها الباحثة إجرائياً بأنها "القدرة على تصميم وابتكار وتطوير وصيانة الدوائر الإلكترونية بكفاءة وإتقان حيث يكتسب هذه المهارة من خلال المعامل افتراضية". 
هي عبارة عن مجموعة من المهارات اللازمة للتعامل مع الأجهزة والأدوات الكهربائية والإلكترونية وتوظيفها في إجراء التمديدات والتوصيلات والدوائر الكهربائية والإككترونية ، بحيث تحقق الرفاهية وحل مشكلات الفرد.(أحمد

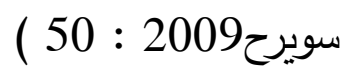

انها قدرة الطالب على فحص العناصر الالكترونية وقدرته على توصيل تلك

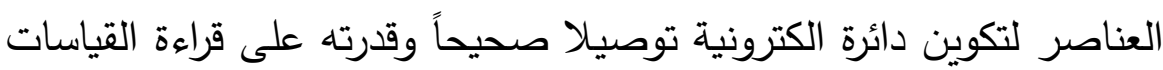
المختلفة وحسابها (جها - تيار - مقاومة ......) بدقة عالية وفى اقل وقت مككن مع مراعاة قواعد الامن والسلامة المهنية.

\section{تخصص الالكترونيات}

هو احد تخصصات التعليم الصناعى يهتم هذا التخصص بدراسة المكونات الأساسية في الدوائر الكهربائية مثل المقاومات, الملفات, والمكثفات بالإضافة إلى لى العناصر الإلكترونية المبنية من أشباه الموصلات مثل الثنائي, الترانزستور , مكبر العمليات والدوائر المتكاملة.

$$
\text { إجراءات البحث: }
$$

اولا: دراسة وتحليل البحوث والدراسات ذات العلاقة بموضوع البحث ،وذلك من خلال المحاور التالية: المحور الاول: التعليم الثانوى الصناعى نظام الثلاث سنوات يتتاول هذا المحور ما يلى: 1. مقدمة- تعريف التعليم الثانوى الصناعى - اهميته - أهدافه- المشكلات التى يعانى منها التعليم الثانوى الصناعى فى مصر • 
تصميم برنامج إثرائى قائم على المعامل الافتراضية لتنمية مهارات أ.سماح محمد ناجى Y. تخصص الالكترونيات : من حيث (اهميته التخصص - اهدافه - الخطة الدراسية لتخصص الالكترونيات بالمدارس الثانوية الصناعية نظام الثلاث سنوات).

المحور الثانى:واقع تدريس مقرر الاساسيات الكهربية فى المدارس الثانوية الصناعية ويتاول هذا المحورما يلى: مقدمة - تعريف مقرر الاساسيات الكهربية - اهمية المقرر - اهدافه - واقع تدريسه المحور الثالث : المهارات العملية فى مجال تخصص الالكترونيات ويتاول هذا المحور ما يلى: تعريف المهارة - خصائص المهارات العملية - مكونات المهارات العملية جوانب تعلم المهارة - مراحل اكتساب المهارات العملية - الاساليب والوسائل المستخدمة فى تعليم وتعلم المهارات العملية - تقييم المهارات العملية - اهمية اكتساب مهارات تكوين الدوائر الالكترونية. ثانيا :تحليل محتوى مقرر أساسيات الهندسة الكهربية ويتم ذلك تبعا للخطوات الاتية: ا ـ وضع قائمة بالمفاهيم وقائمة بالمهارات المستخلصة من تحليل محتوى مقرر أساسيات الهندسة الكهربية . r. عرض قائمة المفاهيم وقائمة المهارات فى صورتها المبدئية على مجموعة من السادة المحكمين للتاكد من صدقهما وإجراء التعديلات فى ضوء آرائهم. r. حساب ثبات قائمة المفاهيم وقائمة المهارات. 
ثالثا : التخطيط العام للبرنامج الاثرائح القائم على المعامل الافتراضية تم الاستعانة بالقائمة النهائية للمهارات التى تم تحديدها فى الخطوة السابقة.

تخطيط البرنامج الإثرائى القائم على المعامل الافتراضية وفق الخطوات الاتية: ا ـ ـ مراجعة نتائج البحوث السابقة المرتبطة بمجال البحث الحالى. r . تحديد اهداف البرنامج المقترح. r. تحديد محتوى البرنامج المقترح. ؛. تحديد الخطة الزمنية لتدريس البرنامج المقترح. ه. تحديد الانشطة التعليمية . 7. تحديد استراتيجيات التدريس V . تحديد اساليب التقييم

^. ضبط البرنامج المقترح كوذلك بعرضه فى صورته المبدئية على مجموعة من الخبراء المحكمين للتأكد من صدقه وصلاحيته ، وإجراء التعديلات فى ضوء

آرائهم.

رابعاً : تصميم محتوى المقرر فى البرنامج الإثرائي المقترح

يتم ذلك تبعا للخطوات التالية : ا ـ تحديد المدى الزمنى r. تحديد الاهداف الاجرائية r. تحديد المفاهيم

ء. تحديد المحتوى العلمى ๑. الخامات والادوات 7. تحديد الانشطة التعليمية 
تصميم برنامج إثرائى قائم على المعامل الافتراضية لتنمية مهارات أ.سماح محمد ناجى

$$
\text { ^. } \text {. . تحديد وسائل ومصديد استراتيجيات التدريس اساليب التقييم التعلم }
$$

• 1. ضبط محتوى المقرر فى البرنامج المقترح ،وذلك بعرضه فى صورته المبدئية على مجموعة من الخبراء المحكمين للتأكد من صدقه وصلاحيته ،

$$
\text { وإجراء التعديلات فى ضوء آرائهم. }
$$

11 ا ـ التجربة الاستطلاعية لمحتوى المقرر فى البرنامج المقترح • خامسا:- اعداد دروس محتوى البرنامج الاثرائح المقترح ويتم ذلك وفق الخطوات التالية:

$$
\text { r r. . . . عوضوان الوحدة }
$$$$
\text { ع. تحديد الاهداف الاجرائية }
$$$$
\text { 0. تحديد المحتوى }
$$$$
\text { 7. تحديد المفاهيم الاساسية }
$$$$
\text { V. تحديد الخامات والادوات }
$$

1. تحديد الانشطة التعليمية 9 . تحديد استراتيجيات التدريس

$$
\text { • ا . تحديد اساليب التقييم }
$$

ا ا . ضبط دروس الوحدة ، وذلك بعرضها فى صورتها المبدئية على مجموعة من الخبراء المحكمين للتأكد من صدقها وصلاحيتها ، وإجراء التعديلات فى ودى

$$
\text { ضوء آرائهم. }
$$

ץ ا ـ التجربة الاستطلاعية للوحدة التدريسية. 
1. اعداد ادوات البحث:(اختبار تحصيل معرفى - بطاقة الملاحظة)

Y. عرض أدوات البحث فى صورتها المبئية على مجموعة من الخبراء

المحكمين للتأكد من صدقها وصلاحيتها ، وإجراء التعديلات فى ضوء آرائهم.

r. حساب ثبات (إختبار التحصيل المعرفى - بطاقة الملاحظة)

سابعاً : تجريب الوحدة المقترحة وتطبيق ادوات البحث

ويتم ذلك تبعا للخطوات التالية:

1. - (اختيار عينة البحث

r. تطبيق ادوات البحث قبلياً على عينة البحث (المجموعة التجريبية -

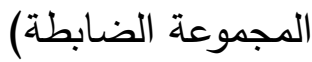

r. تطبيق البرنامج الاثرائى المقترح القائم على المعامل الافتراضية.

ـ. تطبيق ادوات البحث بعدياً على عينة البحث (المجموعة التجرببية -

المجموعة الضابطة)

ثامنـاً : جمع البيانات وتحليلها إحصائياً واستخلاص النتائج. تاسعاً : تفسير نتائج البحث ومناقشتها. عاشراً : توصيات البحث والبحوث المقترحة فى ضوء نتائج البحث. 
تصميم برنامج إثرائى قائم على المعامل الافتراضية لتنمية مهارات أ.سماح محمد ناجى

الفصل الثانى

الأسس النظرية والدراسات المرتبطة

تناول هذا الفصل الأسس النظرية والدراسات المرتبطة والمتمثل فى ثلاث محاور

• • • • • • •

وفيما يلى تفصيل ذلك:

المحور الأول: المعامل الإفتراضية

التعليم الإلكترونى

E.Learning أولًا: مفهوم التعليم الإلكترونى الإسمى

التعليم الالكتروني(E.Learning) مكون من كلمتين هما التعليم والآكتروني،

وما يعنينا هنا هو كلمة الالكتروني، وهي تقابل حرف (e) في المصطلح الانجليزي، وقد اصطلح على أن دخول هذا الحرف على أي مصطلح يعني تحول ذلك المصطلح من المفهوم التقليدي إلى معنى تكون التقنية الالكترونية أحد مفرداته، لذا يعرف التعليم الالكتروني بشكل عام على أنه طريقة فاعلة في التعليم تجمع بين النقل الرقمي للمحتوى وبين توفر الدعم والخدمات التعليمية، والمقصود بتوفر الدعم هو دور المعلم

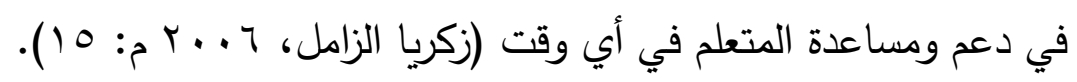
وعلى الرغم من وضوح معنى التعليم الالكتروني، إلا أنه لا يوجد اتفاق تام حول تحديد مفهوم شامل يغطي جميع جوانب مصطلح (التعليم الالكتروني)، فمعظم المحاولات والاجتهادات التي اهتمت بتعريفه نظرت كل منها إلى التعليم الاككتروني

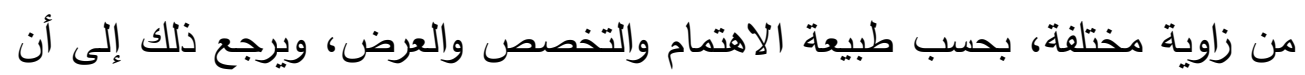


التعليم الاككتروني ما زال في طور التكوين ولم يستقر بعد على حال وهو في حال تعديل مستمر لارتباطه بتكنولوجيا التعليم التي تتمو وتتطور يوماً بعد يوم.

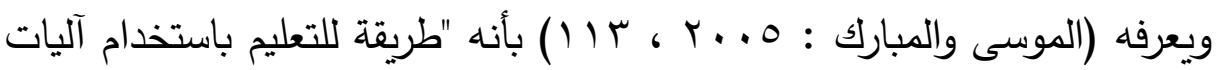
الاتصال الحديثة من حاسب وشبكاته ، ووسائطه المتعددة من صوت وصورة ورسومات وآليات بحث ومكتبات إلكترونية وكذلك بوابات الإنترنت سواء أكانت عن من بعد أم فى الفصل الدراسى أى استخدام التقنية بجميع أنواعها فى إيصال المعلومة للمتعلم باقصر وقت وأقل جهد وأكبر فائدة.

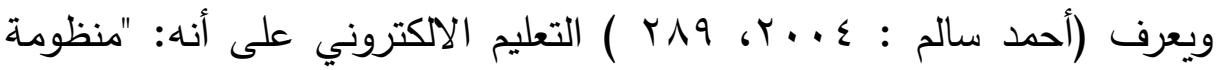
تعليمية لتقديم البرامج التعليمية أو التدرببية للمتعمين أو المتدربين في أي وقت وفي أي مكان باستخدام تقنيات المعلومات والاتصالات التفاعلية مثل: (الانترنت،الإذاعة، والقنوات المحلية والفضائية، الأقراص الممغنطة، التليفون، البربد الالكتروني، أجهزة الحاسوب، المؤتمرات عن بعد، وغيرها) لتوفير بيئة تعليمية تعلمية فاعلة متعددة المصادر بطريقة متزامنة في الفصل الدراسي أو غير متزامنة عن بعد، دون الالتزام بمكان محدد اعتماداً على التعلم الذاتي والتفاعل بين المتعلم والمعلم. ويضيف مانك ( Mank , 2005 (أنه ذلك النوع من التعليم الذي يعتمد على لئ استخدام الوسائط المتعددة وشبكات المعلومات والاتصالات (الإنترنت) والتي أصبحت وسيطاً فاعلاً للتعلم الإكتروني، ويتم التعليم عن طريق الاتصال والتواصل بين المعلم والطالب وعن طريق التفاعل بين الطالب ووسائل التعليم الإلكتروني الأخرى، كالدروس الإكترونية والمكتبة الإكترونية والكتاب الإلكتروني ( حاتم السيالى ، - $(r T: r \cdot) \leq$

يُلاحظ من التعريفات السابقة أن التعليم الإلكتروني هو ذلك النمط من التعليم الذي تتم فيه كل إجراءات الموقف التعليمي التعلمي إلكترونياً ، بحيث يكون فيه

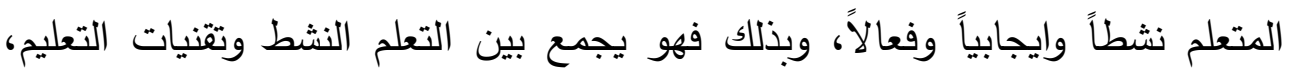


تصميم برنامج إثرائى قائم على المعامل الافتراضية لتنمية مهارات أ.سماح محمد ناجى وينمي المهارات العليا، كما أنه يراعى خصائص المتعمين المختلفة، من سرعة تعلمهم، والمكان والوقت المناسبين لتعلمه بالإضافة إلى مراعاة تفضيلات المتعلمين، محققين بهذا التعريف الشعار الأكثر رواجاً للتعلم الإكتروني وهو: في أي وقت، وفي

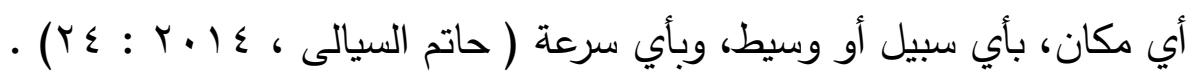
ثانيًا: أنواع التعليم الإلكتروني باني أنياي

ينقسم التعليم الإلكتروني إلى نوعين رئيسي، هما: ا. التعليم الإلكتروني المتزامن: حيث يجتمع في هذا النوع كل من المعلم والطلبة في آن معاً ليتم بينهم الاتصال سواء اكان بالنص او بالصوت او

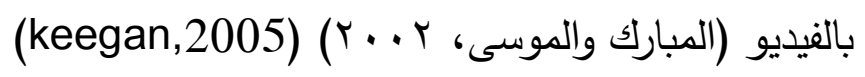

r. التعليم الإلكتروني غير المتزامن: حيث يتصل المعلم بالطلبة بشكل غير مباشر من خلال عرض بعض المعلومات عن المادة الدراسية مثل الخطة لإله الدراسية للمادة أو بعض المصادر للحصول على المعلومات حول المادة الدراسية أو وضع إرشادات للتعامل مع المادة التعليمية. (عبد الحميد بسيوني،

2008 ؛ مها العبد الكريم، 2008 ).

ثالثًا: متطلبات التعليم الإلكتروني:

يتطلب تطبيق التعليم الإكتروني وتوظيفه والاستفادة من توفير مجموعة من المتطلبات المادية وغير المادية تتمثل بتوفير الإمكانات المادية والتي تتمثل في الأجهزة والمعدات والتجهيزات والأثاث والأماكن التي يتم الاعتماد عليها واستخدامها، وتوفير البرامج اللازمة، والمكونات الفنية، وتوفير القوى البشرية من المصمدين والمدربين، والمتخصصين بتدربب الفئات المشتركة، وتطوير العنصر البشري من

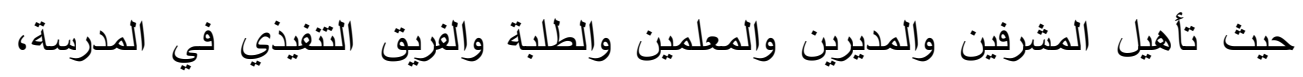
واشراك القطاع الخاص في بناء أسس التدريب والتعليم الإكتروني، وتوظيف عناصر وين وين وين 
التكنولوجيا التي نحتاجها لخفض كلفة التعليم الإلكتروني، وترسيخ الخبرات المحلية لضمان ربط التجربة بثقافة المجتمع واحتياجاته، واستعراض وتبني الخطط والخبرات السابقة للدول المتقدمة التي سبقتنا في التعليم الإكتروني للاستفادة من تجاربها في

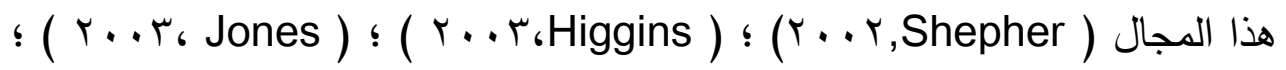

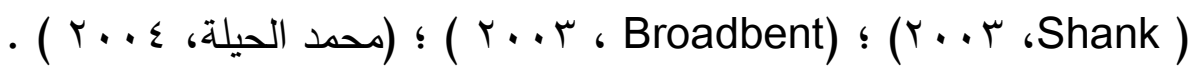
ويرى (محمد خميس r + . r ) أن تطبيق التعليم الإلكتروني يتطلب دراسة التعليم الإلكتروني، من حيث مواصفاته، وخصائصده، وامكاناته، وفوائده، ومزاياه، والصعوبات الهيت والمعوقات التي يساهم في حلها وكيفية تطبيقه، ودراسة الفائدة الاقتصادية والتعليمية من استخدام التعليم الإلكتروني قبل البدء بالتخطيط له حتى لا نضيع الوقت الجهد والمال إذا اثبت عدم فائدته، والتخطيط الثامل والصحيح لتطبيق التعليم الإكتروني بحيث يساهم في عملية التخطيط جميع المشاركين في العملية التعليمية، وتهيئة الظروف المناسبة لتطبيق التعليم الإكتروني كتهيئة النظام التعليمي القائم واجراء التغيرات اللازمة لعملية التغيير، وتحديد الميزانية اللازمة لعملية التطبيق وتوفيرها والتي تعتبر من أكثر الأمور أهمية في عملية تطبيق التعليم الإكتروني، وتوفير الكوادر البشرية المؤهلة والممتلكة للكفايات اللازمة لتطبيق التعليم الإلكتروني قبل البدء بالمشروع، وتوفير متطلبات التعليم الإلكتروني المادية من بنية تحتية ومواد وتجهيزات وأجهزة، وتطبيق تجارب على التعليم الإلكتروني قبل البدء بتطبيقه حيث يتم البدء بتجارب مصغرة ثم يتم التوسع تدريجيا لكي يتم تجاوز المعوقات والصعوبات التمبع التي تواجهه.

\section{دور المعلم والمتعلم في ظل التعليم الإلكتروني:}

إن الدور الذي يقوم به المعلم في التعليم الإلكتروني أكثر أهمية من دوره في

التعليم التقليدي: - 20 - 20

فهو يقوم بتصميم العملية التعليمية الخاصة بمادته بشكل كامل. 
تصميم برنامج إثرائى قائم على المعامل الافتراضية لتنمية مهارات أ.سماح محمد ناجى

ويوظف منتجات التكنولوجيا بشكل فعال في عملية التعلم.

ويشجع الطلبة على التفاعل في عملية اكتساب المعرفة.

ويوجه ويرشد الطلبة إلى الطرق المناسبة لاكتساب المعرفة .

ويساعدالطلبة على تطوير تعلمه الذاتي، ويتواصل معهم عبر البريد

الإككتروني.

ويقوم بتصميم الكتب والمواقع الإكترونية ويعمل على نشرها.

ويوظف الشبكة العنكبوتية العالمية في التعليم.

ويتعاون مع زملائه من المعلمين ليشكل فريق عمل تعاوني ( عوض التودري،

. $(r . . \varepsilon$

ويتيح التعليم الإكتروني للطالب أن يكون نشطاً وفعالاً ومشاركاً في عملية تعلمه

وفق قدراته وامكاناته الخاصة وسرعته الذاتية بحيث يصبح الطالب محور العملية

التعليمية (عبد الرحمن التميمي، ج + . r) .

رابعًا: فوائد استخدام التعليم الإلكترونى:

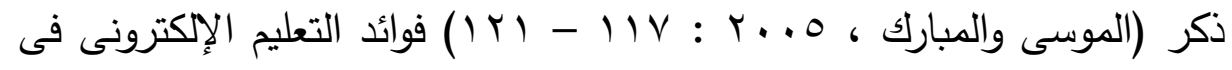

النقاط التالية:

ا. إمكان الاتصال بين الطلبة فيما بينهم والطلبة والمدرسة : وذلك من خلال

سهولة الاتصال ما بين هذه الاطراف.

r. الإسهام فى وجهات النظر المختلفة للطلاب: وذلك من خلال المنتديات الفورية التى تتيح طرح الآراء المختلفة التى تتعكس على المتعلم وتكون لديه

$$
\text { معرفة وآراء قوية وسديدة. }
$$


r. الإحساس بالمساواة : ذلك أن أدوات الاتصال تتيح لكل طالب فرصة الإدلاء برأيه فى اى وقت ودون حرج وهذه الميزة تفيد أكثر الطلاب الذين يشعرون بالخوف واللهفة والقلق.

ع. سهولة الوصول الى المعلم : ويعد البريد الإكترونى لـ-mail وسيلة مفيدة ليتواصل الطالب مع المعلم فى اي وقت وفى ایى مكان. ๑. إمكانية تحوير طرق التدريس: وذلك بالتتاوب بين الطرق المرئية والمسموعة والمقروءة حسب ما يناسب كل طالب. 7 ـ ملاءمة أساليب التعليم المختلفة: ذلك أن التعليم الإلكترونى يتيح للمتعلم التركيز على الأفكار الهامة بسبب كون المهام مرتبة ومنسقة سهلة ومحدة.

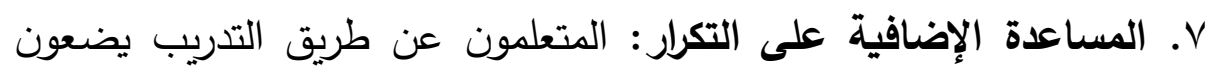
أفكارهم فى جمل معينة ليعبروا عنها وذلك يعنى تكرار المعلومات ورسوخها فى الذهن.

^. توافر المناهج طوال اليوم وطوال الأسبوع: وذلك يتيح لكل متعلم أن يتعلم فى الزمن الذى يناسبه.

9. الأستمرار فى الوصول الى المناهج: فالطالب يستطيع الحصول على المعلومة فى اي وقت اثثاء او خارج اوقات الدوام.

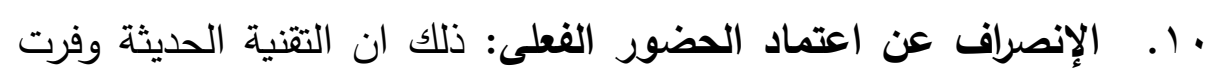
طرائق للاتصال دون الحاجة للتواجد فى زمان ومكان محدد. 11. سهولة وتعدد طرائق تقويم تطور الطالب: وذلك لتوفر التقويم الفورى فى هذه التقنية. ז ا. الاستفادة القصوى من الزمن: لان هذه التقنية وفرت احصول على المعلومة بشكل سريع دون التنقل من مكان لآخر . 
تصميم برنامج إثرائى قائم على المعامل الافتراضية لتنمية مهارات أ.سماح محمد ناجى rا ا. تقليل حجم العمل فى المدرسة: لان التعليم الإلكترونى وفر أدوات تحلل النتائج والاختبارات بشكل سريع ودقيق.

\section{تطبيقات التعليم الالكترونى}

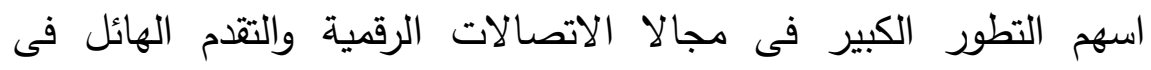
تكنولوجيا المعلومات كانتشار شبكات الحاسوب والثبكة العنكبوتية العالمية

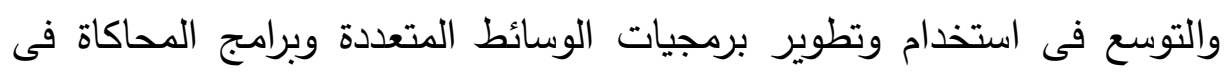

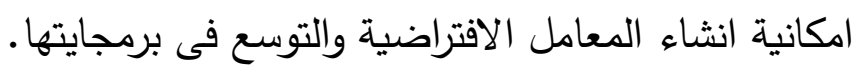

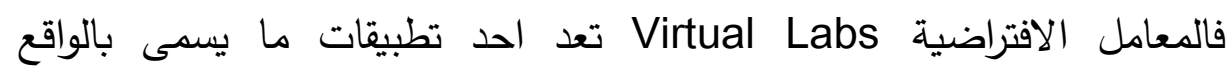
الافتراضى Virtual Reality وهو احد مستحدثات تكنولوجيا التعليم والذى يعد بيئة تعليم مصطنعة او خيالية بديلة عن الواقع الحقيقى وتحاكيه والمتعلم هنا يعيش بيئة تخيلية يتفاعل ويشارك ويتعامل معها من خلال حواسه وبمساعدة جهاز الكمبيوتر وبعض الاجهزة المساعدة (اسماعيل حسن :17 أ.ب).

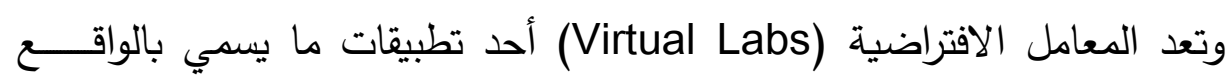
الافتراضي(Virtual Reality) وهو أحد مستحدثات تكنولوجيا التعليم، والذي يعد بيئة

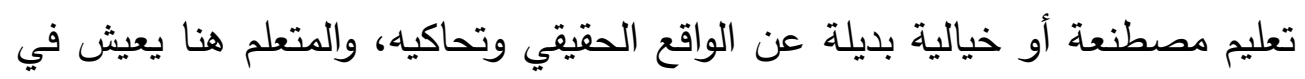

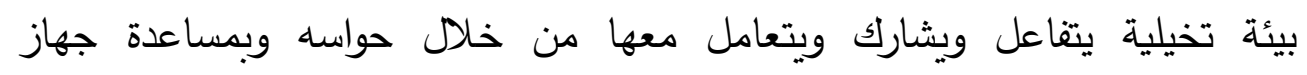
الكمبيوتر وبعض الأجهزة المساعدة. ولقد صمدت المعامل الافتراضية بحيث تحتوى على تجارب افتراضية ومصادر

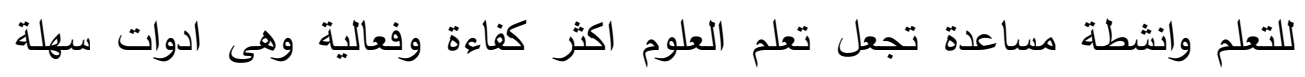

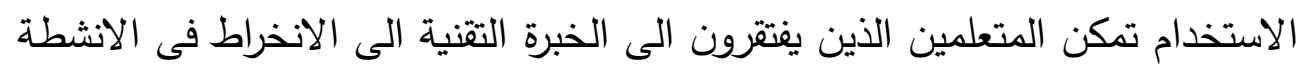

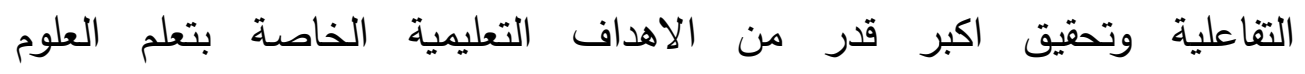
.(Yakov:2008,51) 
ويوضح أندريس (Andres:2009,102) القيمة التربوية للمعامل الافتراضية

بقوله: "لقد اثبتت الملاحظات ان بيئات المعامل الافتراضية أداة تربوية تساعد المتعلمين على تعلم العلوم بطريقة اكثر فعالية من خلال تفاعلهم مع هذه البيئات عن طريق تحكمه فى عملية التعلم ومن ثم فان هذه البيئات يمكن ان تكون فعالة لتعلم العلوم لكافة المراحل التعليمية من المرحلة المتوسطة الى المرحلة الجامعية". ويؤكد التربويون على اعتماد تلك المعامل على طريقة الاكتثاف الموجه فى دراسة العلوم فهى ذات اهمية بالغة فى تدريب المتعلمين على مشاهدات والتطبيق والتنبؤ فهى تتسجم مع ما جاء فى نظرية بياجيه التى اكدت على اهمية العمل والنشاط فى العملية التعليمية وهذا ينسجم كذلك مع متعلمى المرحلة الاعدادية الذين يميلون بطبيعتهم الى النشاط والحركة وحب الاكتثاف. ماهية المعامل الافتراضية:

وتعرف المعامل الافتراضية بأنها بيئة منفتحة يتم من خلالها محاكاة المختبرات الحقيقية والقيام بربط الجانب العلمى بالجانب النظرى ويتم من خلاله تدريس مهارات التفكير ويكون لدى الطلاب مطلق الحرية فى اتخاذ القرارت بانفسهم دون ان يكون لذلك آثار سلبية (Wood field,et al,2004).

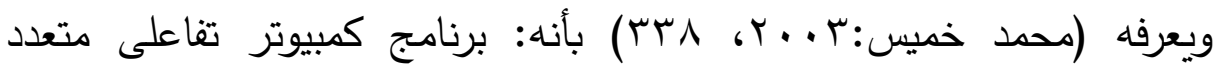
الوسائل يوفر بيئة تعلم اعتبارية مصطنعة بالكمبيوتر تحاكى معامل حقيقية وتمكن المتعلمين من استخدام الادوات والاجهزة المعملية وتداول الاثياء التى تدرك بالحواس المجردة كالذرة وإجراء التجارب والفحوصات الصعبة والخطرة والنادرة فى بيئة آمنة على الخط المباشر بالويب.

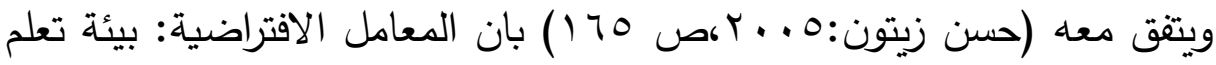
وتعليم افتراضية تستهدف تتمية مهارات العمل المخبرى لدى الطلاب وتقع هذه البيئة على احد المواقع فى شبكة الانترنت وينضوى هذا الموقع عادة على صفحة رئيسية 
تصميم برنامج إثرائى قائم على المعامل الافتراضية لتنمية مهارات أ.سماح محمد ناجى

ولها عدد من الروابط او الايقونات (الادوات) المتعلقة بالانثطة المختبرية وانجازاتها

وتقويمها

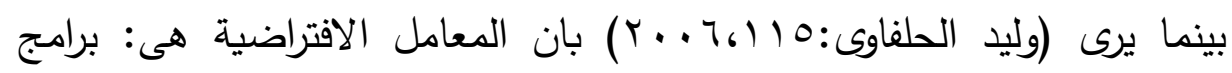
كمبيوترية صمدت بحيث تضع المتعلم فى مواجهة مواقف محاكية للواقع وتحثه على الى التفاعل مع هذا الواقع فى ضوء اسس وقواعد محددة وعلى ضوء هذا التفاعل يصدر المتعلم مجموعة من القرارات والاستجابات.

ويشير (Alexiou,C.\&et al 2008) الى ان المعامل الافتراضية تمثل احد

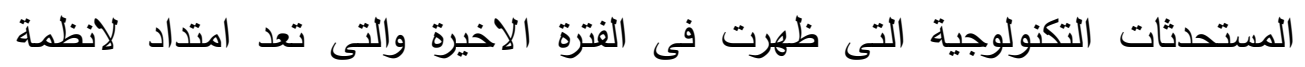

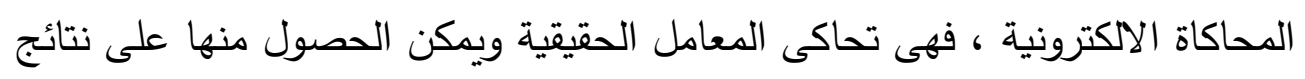
متثابهة لإتنائج المعامل الحقيقية.

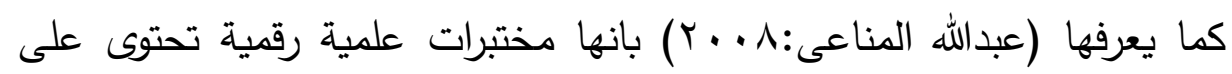
أجهزة كمبيوتر ذات سرعة وطاقة تخزين وبرمجيات علمية مناسبة ووسائل الاتصال بلهال بالثبكة العالمية تمكن المتعلم من القيام بالتجارب العلمية الرقمية وتكرارها ومشاهدة

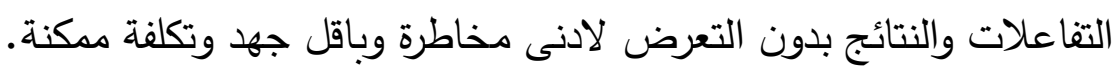

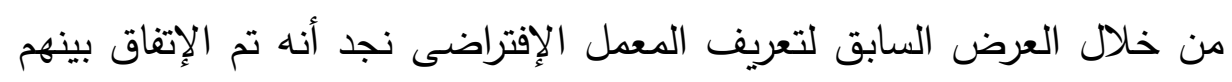

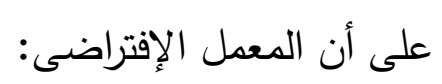

تدعم وتساند دور المعامل التقليدية بالرغم من أن المعمل الإفتراضي يفتتر عنصر تلمس الأدوات.

برنامج كمبيوتر تفاعلى متعدد الوسائل يحاكى المعامل التقليدية. ما بنيت الا على الاساس الذى بنيت عليه المعامل التقليدية.

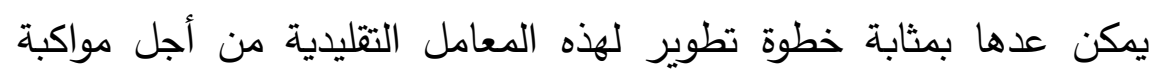
التقدم. تتمى مهارات التنكير واتخاذ الترارات دون ان يكون لذلك اثار سلبية. 
يمكن من خلالها الحصول على نتائج مشابهه للنتائج التى يحصل عليها المتعلم من المعمل التقليدي.

يمكن تكرار التجارب والتفاعلات دون حد اقصى للتكرار دون التعرض لادنى مخاطرة، وباقل جهد. فى الغالب تعويض عن غياب الأجهزة والأدوات المعملية. مميزات المعامل الافتراضية:

المعامل الافتراضية وسيلة تعليمية دهمة وخاصة فى بعض دول اوربا نظراً للميزات العديدة التى تقدمها هذه التقنية فى مجال التربية والتعليم. فالمعامل الافتراضية تتميز بميزات عديدة تدعو الى التاكد على اهميتها وضرورة قبولها وتبنيها كتغيير تربوى مهم فى تدريس المواد العلمية وفى إثراء الجوانب العملية.

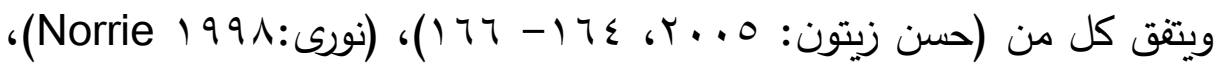
(Carl:2008,151)، ، (Jeetinder:2009,35)

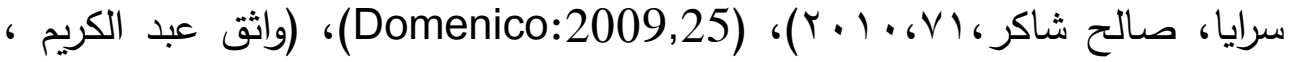

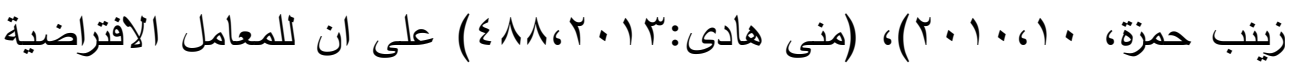
مجموعة من المميزات والتى تتمثل فى: تقليل وقت التعلم الذى يقضيه الطلاب فى المعمل التقليدى. تعوض النقص فى الامكانات العملية الحقيقية لعدم توفر التمويل الكافى. إمكانيته تغطية كل افكار المقرر الدراسى بتجارب عملية تفاعلية وهذا يصعب تحقيقه من خلال المختبر الحقيقى نتيجة لمحدودية الامكانات والمكان والوقت المتاح للعملى. إجراء تجارب يصعب إجراؤها وقتا طويلا فى المختبر التقليدى كونها خطرة او مكلفة ماديا او التى يتطلب إجراؤها وقتا طويلا فى المعمل التقليدى. 


\section{تصميم برنامج إثرائى قائم على المعامل الافتراضية لتنمية مهارات أ.سماح محمد ناجى}

تقديم التغذية الراجعة المناسبة للمتعلمين عن ادائهم المعملى بالسرعة

$$
\text { والكيفية التى يريد. }
$$

جعل الجوانب العملية اكثر متعة وإثارة بالنسبة للطالب. سهولة تجريب المختبرات المختلفة ودراسة اثرها على مخرجات التجربة من خلال لوحات تحكم افتراضية .

إمكانية التفاعل والتعاون مع اخرين فى اجراء نفس التجربة. حماية المتعلم من مخاطر التدريب العملى فى بداية مراحل التعلم. مرونة الاستخدام من قبل الطلاب حيث يمكنهم أداء الانشطة المعملية فى مري اى وقت وفى اى مكان وباى سرعة وبالتالى يمكن الطالب القيام بالانشطة العملية التى فاتته.

تكلفتها المادية قد تكون اقل من التكلفة المادية للمعامل التقليدية. إمكانية وسهولة متابعة إنجاز الطالب وتوجيهه. احتواء برامج المعامل الافتراضية على ادوات تساعد على دعم التجربة مثل الرسوم البيانية والمتحركة والتحليل.

تتيح للمتعلم الفرصة لتعلم المفاهيم المجردة وكيفية حل المشكلات. تقدم عرضا مرئيا للبيانات والظواهر التى لا يمكن عرضها من خلال

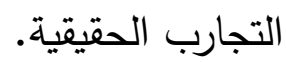

تحقق التزامن بين عملية شرح الافكار النظرية والتطبيق العملى حيث ان التجارب المعملية الحقيقية مرتبطة بجدول منفصل عن المحاضرات النظرية. الشراكة فى بناء وتطوير المختبرات الافتراضية يدعم العملية التعليمية ويقلل من كلفتها ويساهم فى التعاون وتبادل الافكار والمساهمة فى استخدام الاجهزة باهظة التكلفة. 
إضافة طابع اللعب الجاد فى الممارسة العملية يساهم فى جذب اهتمام المتعلمين ويشجع على اندماجهم فى عملية التعلم.

إمكانية نقل التجارب ونتائجها لحافظة الوثائق الاكترونية التعليمية الخاصة بالمتعلم والتى تمثل وسيلة فعالة للتقييم الثامل لادائه. تتيح المختبرات الافتراضية الفرصة لتعريض المتعلم لمواقف يحرم منها في المختبرات الحقيقية نظرا لخطورتها وبالتالي تتكامل معلوماته فيما يتعلق بتلك المواقف. يساعد إنتشار المختبرات الافتراضية وعولمتها على ظهور معايير للتجريب العلمي. تحسين أداء الباحثين نتيجة لتوفير وقت الانتقال الى اماكن تواجد المختبرات البحثية.

\section{معوقات استخدام المعامل الافتراضية:}

ان تقنية المعامل الافتراضية وما تتضمنه من إيجابيات عديدة كاى تقنية لابد ان

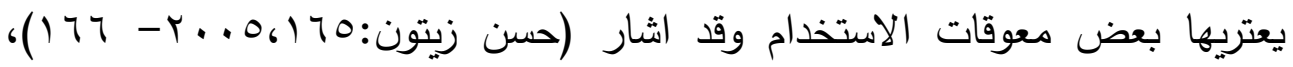
، (Carnevale:2003,2) (منى ) ( نورى(Norrie:1997A.62-63 على ان هناك مجموعة من المعوقات التى قد تحد من استخدام المعامل الافتراضية والتى تتمثل فى: تتطلب اجهزة حاسب آلى ومعدات ذات مواصفات خاصة وذلك لتمثيل الظواهر المعقدة بشكل واضتح. يحتاج تصميمها وإنتاجها الى فريق عمل متخصص من المبرمجين والمعلمين وخبراء المناهج وخبراء المادة الدراسية وعلماء النفس. ندرة المعامل الافتراضية التى تعتمد اللغة العربية فى التعامل معها. نقص التقاعل الحقيقى مع الاجهزة والادوات والمواد والمعلم والزملاء. 


\section{تصميم برنامج إثرائى قائم على المعامل الافتزاضية لتنمية مهارات أ.سماح محمد ناجى}

قد يكون من الصعب القول بان الحاسب يضاهى استخدام المعدات الفعلية فى تعليم استخدام المعدات الفعلية فى تعليم المهارات.

مهارات الاتصال والعمل الجماعى من خلال المحاكاة لن تتافس المهارات

$$
\text { الاجتماعية المكتيبة من التجربة الحقيقية. }
$$

المحاكاة تقدم تجربة تعليمية ضعيفة فى الاهداف العملية والعاطفية مقارنة

$$
\text { بالاهداف المعرفية. }
$$

من المستحيل تأسيس معمل افتراضى يتضمن كل الامكانات التى يحتاجها الطالب فى المعمل الحقيقى. من المحتمل انحصار عمل الطلاب فى التجارب المحددة المبرمجة فى في برنامج المعمل الافتراضى فقط.

\section{اهمية المعامل الإفتراضية فى تدربس منهج اساسيات الهندسة الكهربية:} اذا تتاولنا منهج اساسيات الهندسة الكهربية بالتحليل سنجد انه يحتوى على شقين الثق النظرى الذى يتضمن الموضوعات التالية: المقاومات - المكثفات - الملفات المحولات - الترانزستورات - اشباه الموصلات - التيار الكهربي - فرق الجهد ونظريات الدوائر الكهربية - الدوائر المتكاملة - النبائط الضوئية - المجال المغناطيسي - القوة الدافعة الكهربية وغيرها من الموضوعات التى يتناولها المنهج وتدرس داخل الغرفة الصف اسبوعيا بواقع اربعة حصص متتابعة. ويلاحظ ان هذه الموضوعات هى موضوعات مجردة يجد الطلاب صعوبة فى فهمها ، وتعلمها فرغم ما يقوم به الطلاب من استخدام للكهرباء بصورة يومية فى حياتهم ، فهم يذهبون الى المدرسة ، ولديهم بعض المفاهيم الخاصة ، والمتكونة لديهم حول الكهرباء ، ونتيجة لاستخدام الاساليب التقليدية التى لا تتناسب مع طبيعة موضوعات الهندسة الكهربية المجردة ؛ يتكون لدى الطلاب مفاهيم خاطئة ، ومن هذه المفاهيم الخاطئة على سبيل المثال (نجوان حامد:2007,99): 
عناصر الدائرة الكهربية لها طرف واحد فقط ، لذلك فإضاءة المصباح

$$
\text { الكهربى تحتاج الى سلك واحد فتط. }
$$

التيار الكهربى له اتجاهان ، لذلك يعتقد الطلاب ان البطارية لها طرفان

$$
\text { والمصباح له طرف واحد فقط. }
$$

عناصر الدائرة الكهربية مثل المقاومة تستخدم التيار الكهربى.

$$
\text { لا يوجد فرق فى الجهد بين طرفى البطارية. }
$$

ويرجع اسباب الفهم الخاطئ لهفاهيم الكهربية ، الى ان الدفاهيم المتكونة لدى الطلاب حول الكهربية غالبا ما تكون مختلفة عن المفاهيم التى درست وعلمت داخل الفصل الدراسى ويمكن إرجاع ذلك إلى بعض الأسباب منها استخدام طرق التدريس التقليدية وتصميم المقررات الدراسية واستخدام الوسائل التعليمية ثنائية البعد فى تدريس مفاهيم مجردة.

والثق الاخر وهو الجزء التطبيقى المعملى للجزء النظرى الذى يحتوى على ثمانى تجارب مقسمة على العام الدراسى اربعة تجارب فى الفصل الدراسي الاول واربعة تجارب فى الفصل الدراسي الثانى تدرس بواقع حصة واحدة اسبوعيا يقوم فيها المعلم باجراء التجربة امام الطلاب جميعا ومع الكثافة العددية للفصول يصعب اتقان التجربة او اعادة اجراءها فى هذا الوقت الضيق ومع هذه الكثافة لذا اذا اوجدنا البديل وهو ان يقوم المعلم بشرح مكونات التجربة واختبارها امام الطلاب ويقوم الطالب باعادة اجراءها من خلال المعمل الافتراضى بعيدا عن مخاطر الكهرباء او الخوف من تلف الاجهزة فسوف يعود على الطالب بالنفع لما فى ذلك من تشويق واثارة حيث انه يتعامل مع عناصر التجربة والاجهزة المستخدمة بشكل افتراضى فتتولد لديه الدافعية نحو التجريب بل ومن الممكن الابتكار • 
تصميم برنامج إثرائى قائم على المعامل الافتراضية لتنمية مهارات أ.سماح محمد ناجى المحور الثانى : البرامج الإثرائية

\section{Enrichment Programs البرامج الإثرائية}

يحتل البرنامج الإثرائى مكانة بارزة فى الفكر التربوي المعاصر حيث يهدف إلى إثراء المناهج الدراسية ولإضفاء البعد الواقعى والوظيفى عليها. ونبعت هذه النظرة من الإيمان بمبدأ التربية المستمرة والمجتمع المتعلم والمستمر فى التعليم • الإثراء لغةً مأخوذ من الفعل "أثرى، يُثرى، إثراء فهو مُشير والمفعول مُثرى وأثرى الرجل كثُر ماله، وأثرت الأرض كثر ثراها، وأثرى الثئ جعله غنيا وزاده (احمد براء

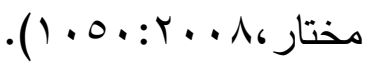
اما الإثراء اصطلاحا : يعنى التوسع والتعقى فى جوانب التعلم المتضمنة فى موضوع دراسى واحد او وحدة دراسية فى منهج بعينه او فى جميع جوانب المنهج

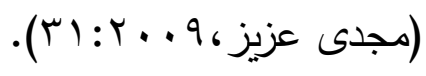

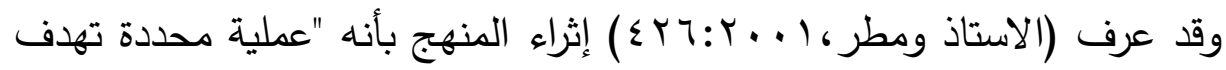
الى إحداث تنمية او زيادة كمية او نوعية لعنصر او اكثر من عناصر المنهاج لتوجيه التعليم او تسهيل حدوثه او التاكد من فاعليته فى مجال معين." وقد اتقق معه (عفانه واللولو، ؛ . . :0) فى ان عملية إثراء المنهج تعد عملية علاجية محدودة تتناول الجزيئات التى تكتثف ويظهر فيها المشكلات ، وبهذا فان إثراء المنهج قد يكون بزيادة او تتمية فى الاهداف او تحسين فى المحتوى نوعا او كما او كليهما. ماهية البرامج الإثرائية: عرف (محمد وهبه، V. . . . (T) البرنامج الإثرائى على انه "زيادة الخبرات التعليمية المقدمة للطلاب بما يتناسب مع ميولهم وقدراتهم وأستعداداتهم". 
وقد اتفتت معه (شيماء عطا،9. . . .99) حيث عرفت البرنامج الاثرائي بانه "برنامج يقدم دعما جزئيا منظما للمتعلمين متمثلا فى شكل انشطة أو خبرات إضافية أو قراءات نظريـة تتلائم مع إحتياجاتهح".

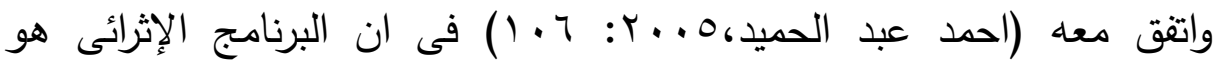
"إغناءالبرنامج التربوى وتزويد الطلاب فى المراحل التعليمية المختلفة بنوع معين من الخبرات التعليمية يختلف عن الخبرات المقدمة لهم فى الفصل الدراسي المعتاد من حيث: المحتوى والمستوى والجدة والاصالة الفكرية". بينما عرف (نصر محمود،ع . . PV:Y) البرامج الإثرائية على انها "هى الدراسة الإضافية او مجالات التعليم التى توجد دائما فى المنهج المقرر".

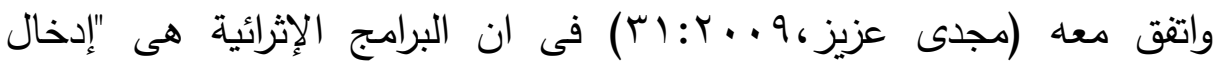
تعديلات أو إضافات على المناهج المقررة على الطلاب فى المجالات المعرفية والإنفعالية والنفس حركية، لتواكب مستوى الطلاب الفائقين أو لتسهم فى رفع مستوى الطلاب العاديين وقد يكون إثراء عن طريق العمق أو إثراء عن طريق الإتساع" وبمراجعة التعاريف الإجرائية السابقة يمكن استخلاص التالى:

البرامج الإثرائية عبارة عن انشطة تعليمية غير تقليدية.

البرامج الإثرائية تسعى الى تكثيف معلومات الطلاب وتعميق خبراتهم. تقدم البرامج الإثرائية للطلاب بصورة شائقة تستثير دافعيتهم نحو التعلم. تتمى البرامج الإثرائية القدرات: الإبداعية والإبتكارية لدى الطلاب. البرامج الإثرائية تناسب إحتياجات الطالب الفعلية ويشارك الطالب فيها

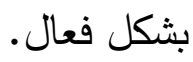
تتسم البرامج الإثرائية بمناخ من الثقة والقبول والاحترام المتبادل بين المعلم والطالب. 
تصميم برنامج إثرائى قائم على المعامل الافتراضية لتنمية مهارات أ.سماح محمد ناجى

تراعى البرامج الإثرائية الفروق الفردية بين الطلاب من خلال اساليب التعلم

المستخدمة.

تقدم البرامج الإثرائية فى صور متعددة منها: أنثطة الزيارات الميدانية -

أنشطة الألعاب التعليمية- القراءات الإثرائية - أنشطة إعداد المجلات

وكتابة التقارير •

يصمح لمواكبة مستوى الطلاب الفائتين او للمساهمة فى رفع مستوى الطلاب العاديين.

ترتبط بحاجات الطلاب فى المرحلة الثانوية كالحاجة الى النظرة الإجابية نحو الذات والمجتمع وتطوير الذات وتنمية الموهبة كسلوك وحب التساؤل والتجريب والتعلم الذاتى وإثارة التحدى والبحث بعدق وإتاحة السلوك الإبداعى والوصول إلى المستويات العليا للوظائف العقلية (فليب كارتر

$$
\begin{aligned}
& \text { وراسل كين،A . . . Y V ) ). } \\
& \text { اهداف البرامج الإثرائية: - }
\end{aligned}
$$

يعد الإثراء التعليمى خبرات إضافية هادفة ومنظمة ومحددة ومهارات بحثية وتفكيرية تتسم بالعمق والتشعب والمتعة والتحدى والتفاعل تضاف الى المحتوى العلمى لإنى الذى يدرسه الطلاب وتتلاءم مع احتياجاتهم فى المجالات المعرفية والمهارية والوجدانية.

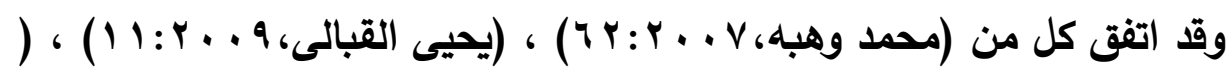

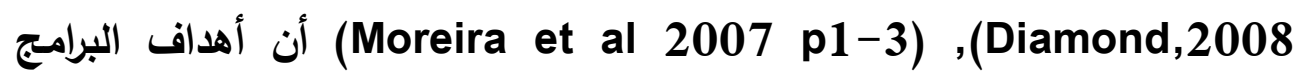
الإثرائية تتمثل فى الآتى: ا . توفير محتوى علمى ومصادر تعلم لا تتوفر فى المحتوى الدراسى العام. 
r. توفير خبرات تعليمية تعلمية عميقة وواسعة الى جانب المحتوى المعتاد

لتنمية القدرات العقلية للمتعلمين.

r. استكثاف مجالات متنوعة فى العلوم والمعارف.

ء. المساعدة فى تعلم المهارات الاساسية بناءً على احتياجات المتعلمين وليس

$$
\text { بناءً على أعمارهم. }
$$

๑. التركيز على تتمية المهارات النوعية التى تساعد على فهم المبادئ الاساسية

لاصدار التعميمات بدلاً من التركيز على مهارات التفكير الكمية للحقائق.

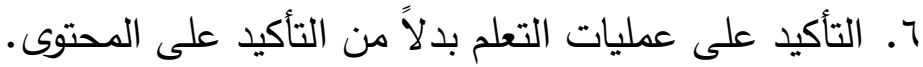

V. ترتيب المعلومات المقدمة فى المحتوى ترتيباً أفقياً.

^. التركيز على الكيف وليس الكم أى أنه أفضل للمتعلم أن يجد ثلاثة حلول لمشكلة واحدة بدلاً من أن يحل ثلاث مشاكل متشابهة.

\section{اهمية البرامج الإثرائية:--}

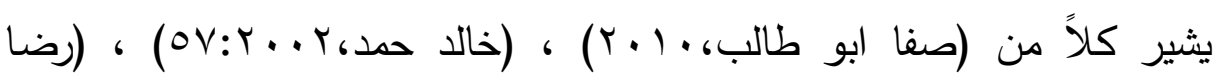

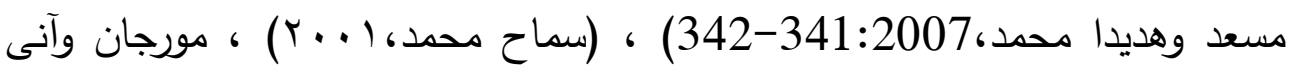

(الى ان أهمية البرامج الإثرائية تكمن فى التالى: (Morgan Anne, 2007 p26) تكسب الطلاب نشاطاً وحيويه وفاعلية اكثر داخل الصف.

تساعد الطلاب على ربط خبراتهم السابقة بالجديدة بشكل يضمن استمرارية

التعلم

اكتساب المهارات اللازمة فى المجالات المعرفية والنفسحركية والوجدانية -

الاجتماعية.

ترجع أهمية البرنامج الإثرائى التعليمي الى كونه ينقل المتعلم من حالة التلقى السلبى الى حالة التفاعل الإيجابى فى اثثاء الحصة ويعد ادخال الانشطة الإثرائيه في المنهج المدرسي احد الاتجاهات المعاصرة لتطوير 
تصميم برنامج إثرائى قائم على المعامل الافتراضية لتنمية مهارات أ.سماح محمد ناجى

المناهج الدراسية تحقيقا لمبدأ التعلم للجميع وتحقيقا لجعل المتعلم محورا

للعمليه التعليميه والاهتمام بالتعلم النشط.

إن البرامج الإثرائية هى احد الخبرات التى يوفرها النظام التربوى للطلاب المتفوقين وغير المتفوقين حيث يحصلون من خلالها على زاد تربوى يشبع ما لديهج من طاقات كامنة.

حيث تحتوى البرامج الإثرائية على مجموعة من الخبرات التعليمية والانشطة الإثرائية والتى تعد جزءا اساسيا من المنهج الدراسى وهى أنشطة غير الإنراسئ تقليدية تستخدم لتوسيع المجال المعرفى لإى الطلاب وتوسيع الكفاءات والمهارات الاساسية ودعم المقرارات الدراسية بموضوعات إضافية ودعم المنهج الاختيارى من خلال الاشتراك فى الفعاليات المختلفة ودعم عمل

$$
\text { الطلاب داخل وخارج المدرسة. }
$$

ومما سبق يتضح مدى اهمية البرامج الإثرائية لطلاب المدارس الثانوية الصناعية والذى من شأنه جعلهم يقبلون على المدرسة بشكل فعال كما ستحفزهم للمشاركة فى ملى لإنى الانشطة والتمارين والابتكار وحرصهم على حضور المعامل والورش.

\section{خصائص البرامج الإثرائية:}

تتميز البرامج الإثرائية بعدة خصائص تتمثل فى أنه:

يعد امتداداً ومكملًا للبرنامج العام يحتوى على نشاطات حرة يقوم بها لهاديا

الطلاب بإشراف معلميهم لتوسيع دائرة معارفهم ومهاراتهم.

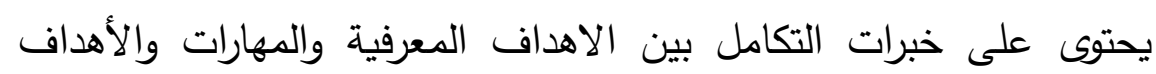

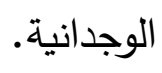

ينظم المعارف والنشاطات بطرق تساعد على تصميم التعلم واستخدام

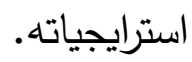
يركز على عمليات التفكير العليا وطرق التعليم. 
يتصف بالمرونة فى مواده وخبراته.

\section{البرامج الإثرائية ومقرر الاساسيات الهندسية:-}

ويعد توظيف البرامج الاثرائية فى العملية التعليمية ضرورة ملحة فالبرامج الإثرائية

لم تعد حكراً على الطلاب الموهوبين فقط ولكن اتسعت لتشمل الطلاب والطالبات العاديين فمن خلال البرامج الاثرائية يمكن تحقيق الآتى:

التعمق فى المادة التعليمية وإثراء المعلومات فيها لتوسيع الحصيلة المعرفية وتعميقها بالمناهج التربوية وبطبيعة الحال سيحظى مقرر اساسيات الهندسة الكهربية بما يحويه من عناصر كهربية والكترونية وبعض الدوائر الإلكترونية كتطبيق عملى على توظيف العناصر الكهربية والالكترونية داخل هذه الدوائر ببرناهج إثرائى يقوم على المتعلم حيث سيكون دوره

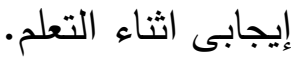
مساعده الطالب فى الاعتماد على نفسه فالمعلم لم يعد ملقناً ومرسلاً للمعلومات بل مرشداً وناصحاً ومحفزاً للحصول على المعلومات مما يشجع على إستقلالية الطالب واعتماده على نفسه. ومن مميزات البرامج الإثرائية ايضاً انها تعمل على التخفيف من صعوبة الموضوعات التعليمية المجردة فهى تساعد على المشاركة الإيجابية والفعالة للطالب للحصول على الخبرة ويصاحب عملية التعلم استمتاع باكتساب

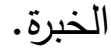


تصميم برنامج إثرائى قائم على المعامل الافتراضية لتنمية مهارات أ.سماح محمد ناجى المحور الثالث: المهارات العملية

مفهوم المهارة:

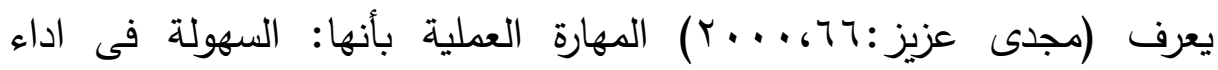
استجابة من الاستجابات او السهولة فى القيام بعمل من الاعمال بدقة وعلى اكمل

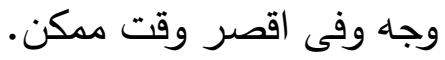

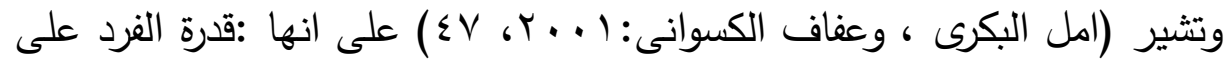
اداء الاعمال بكفاءة اكبر من المعتاد.

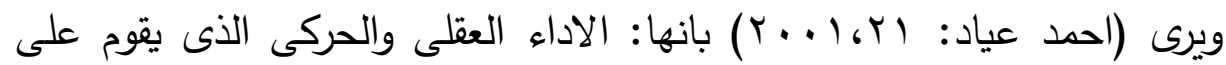

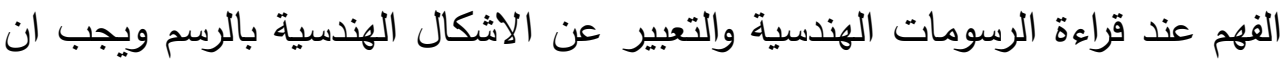

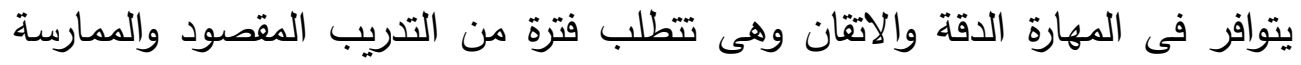
المنظمة كما تتطلب الارشاد والتوجيه المستمر من قبل المعلمين.

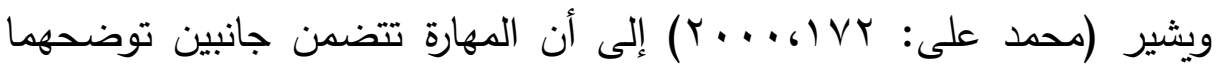
المعادلة التالية وهما الجانب المعرفى وآخر نفس حركى: المهارة = القدرة + المعرفة وهى القدرة المكتسبة التى تمكن المتعلم من انجاز اعمال تعليمية بكفاءة وإتقان

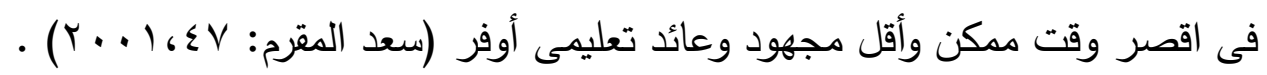

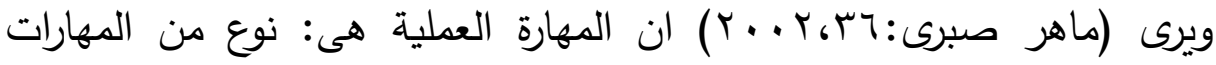
النفسحركية التى تتطلب قدرا عاليا من التآزر الحسى الحركى كمهارات الاداء اليدوى الهاء

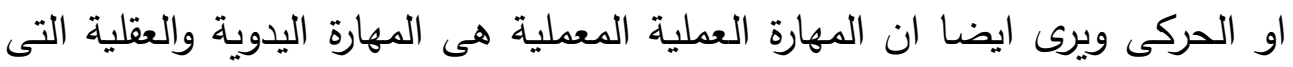

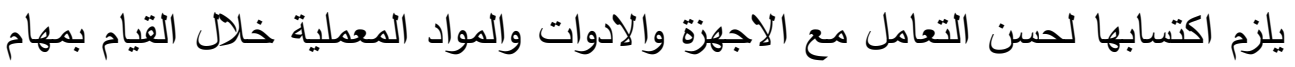
وانشطة العمل المعملى. 


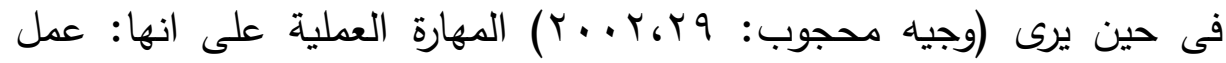
حركى يحتوى على عدد من الاستجابات الادراكية الحسية التى تكتسب بالتعلم فالمهارة العملية: هى عمل وواجب حركى.

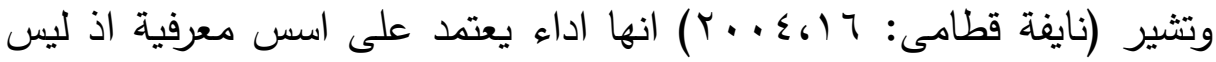
هنالك اداء بدون اسس نظرية فى اي مجال من مجالات المعرفة والعمل.

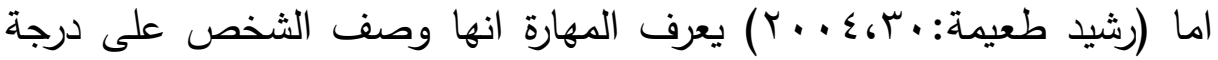
من الكفاءة والجودة فى الاداء.

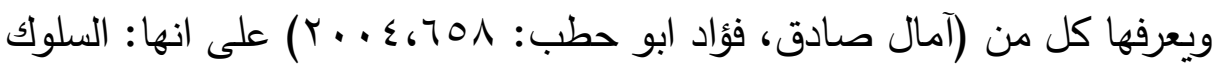
المتعلم او المكتسب الذى يتوافر له شرطان جوهريان: اولهما ان تكون موجها نحو إحراز هدف معين وثانيهما ان تكون منظمة بحيث تؤدى الى احراز الهدف فى اقصر وقت واقل جهد ممكن.

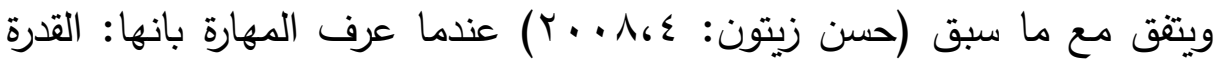
على اداء عمل معين وهذا العمل يتكون فى الغالب من مجموعة الاداءات او العمليات الاصغر التى تتم بشكل متسلسل ومتتاسق فتبدو مؤلفة بعضها مع بعض. وفى ضوء ما سبق عرضها من تعاريف لمفهوم المهارات العملية يمكن استخلاص مجموعة من النقاط الهامة ومن هذه النقاط ما يلى : 1. تثير السرعة الى اقتصاد وقت الاداء وتقاس بالزمن المستغرق فى تقديم السلوك المطلوب فى ضوء مواصفات الجودة او المعايير المتفق عليها وتقاس بمجموعة الاداءات الصحيحة للسلوك او الاستجابة. r. ويشير العمل الى المهمة المطلوب انجازها ويتطلب ذلك ممارسة نشاط معين او نقد. r. تهدف المهارة العملية الى تحقيق هدف معين. 
تصميم برنامج إثرائى قائم على المعامل الافتراضية لتنمية مهارات أ.سماح محمد ناجى

ء. ان للمهارات ثلاث جوانب تعلم ( الجانب المعرفى العقلى، الجانب

$$
\text { النفسحركى المهارى، الجانب الوجدانى). }
$$

๑. يمكن تحليل المهارة العملية الى مهارات فرعية ومهام.

7. تتصف المهارة العملية بالسرعة، والدقة، والفهه، والقدرة على إنهائها فى اقل

$$
\text { زمن، واقل مجهود. }
$$

V. تتبع خطوات، وإجراءات معينة متتابعة متسلسلة اثناء تتفيذها.

^. تشمل المهارة العملية الاعمال العقلية او البدنية او الاثثين معا.

مراحل اكتساب المهارة العملية :

يرى (ابو بكر عابدين: 9199 1، 9 1) انه لا يتم اكتساب الافراد للمهارات العملية فى لحظات قليلة بل يستغرق ذلك وقتاً وإن ذلك الوقت اللازم لاكتساب المهارة يختلف من شخص لاخر طبقاً لقدراته وهذا شئ طبيعى وعلى كل طالب ان يمر بمراحل حتى يكتسب المهارة.

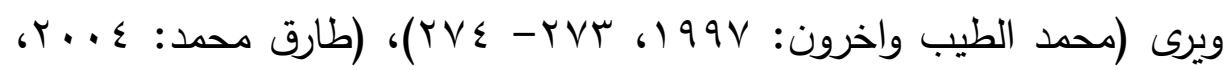

$$
\text { اولاً المرحلة المعرفية: ان هذه المراحل هى: }
$$

ان تقديم جرعات معرفية منتظمة عن تحليل المهارة العملية او مكوناتها وحركاتها وعلاقة كل منها بالاخرى تجعل للمتعلم القدرة على تكوين بنية معرفية تصويرية لفظية عن عناصر المهارة وتثابكها وحتى ينجح المدرب، الاخصائى فى تعليم المهارات العملية، عليه فعل الاتى:

ا. لابد ان يقدم صورة متكاملة عن المهارة بالامثلة والصور والاداء العملى. r ب. يقوم بتوضيح مكونات وعناصر المهارة العملية وتحليلها وفق جرعات محددة طبقا لمستوى التعقيد فى المهارة العملية حتى يتقنها المتعلم. 
r. فتح الحوار والمناقشة مع المتعلمين لتكوين خطة لفظية متعاقبة حول

$$
\text { خطوات المهارة }
$$

ع. يضع المتعلمين فى خبرة تعرف بالتدريب الاستطلاعى ويجب ان يلاحظ كل فرد على حدى ويسجل كل الملاحظات على بطاقة تقويم مبدئية، مع ملاحظة ان التقدم السريع ليس مؤشراً للتفوق فى المهارة مسبقاً. 0. ان يقوم اثناء التدريب بعمليات التدعيم المعنوى والتغذية المرتدة.

\section{ثانياً: مرحلة التثبيت:}

وتعتبر تلك المرحلة هى المرحلة الحقيقية فى التدريب على اكتساب المهارة وقد تمتد من اسابيع الى شهور طبقاً لنوع المهارة واستعداد المتعلم،الهدف الرئيسى فيها تصحيح اسلوب اخراج المهارة، والمؤشر هنا هو اختزال الاستجابات الخاطئة بالتدريج لتصل الى الصفر وعندما يصل المتعلم لمستوى متقدم من التدريب والخبرة فانه يكتسب القدرة على تتظيم سلاسل المهارة . ثالثاً: مرحلة السيطرة الذاتية:

وفيا يكون المتعلم قد اكتسب إجادة اداء المهارة العملية بدقة اى اصبح يؤدى حركات العمل بدون اخطاء وتاتى تلك المرحلة لتحقيق السرعة فى الاداء اى الجمع بين الدقة والسرعة، فالدقة هى المسئولة عن الاداء بدون اخطاء، اما السرعة فهى تأدية المهمة بسرعة والتفاعل الحجمى بين الدقة والسرعة ضرورى لانها مهارة وحتى لهى تتجح هذه المرحلة لابد على المعلم ان يقوم بما يلى: الاشراف على متابعة المتعلم فى التخلص من اثر تثبيت المنبهات والانشطة الخارجية حيث يتم تقليل او منع العوامل المتداخلة الخارجية التى من شأنها كف المهارة ومعنى ذلك ان المتعلم يصل الى مرحلة تكوين مراكز عصبية عليا فى المخ. 


\section{تصميم برنامج إثرائى قائم على المعامل الافتراضية لتنمية مهارات أ.سماح محمد ناجى}

الاشارة للاداء الامثل للوصول الى المستوى اللاارادى مثل ممارسة الالة الكاتبة بدون النظر الى المفاتيح لان الجهاز العصبى يعطى الاوامر للاصابع للحركة فى مدى محدود واى خطأ فيه يؤدى لتقليل مستوى المهارة. التوجيه الى كثرة التمرين الصحيح (بدون اخطاء) سيؤدى بالفعل لتكوين برنامج عصبى - نفس حركى - يتم استدعاؤه من المخ بسرعة بمجرد المثول امام العمل طبقا لنوع المهارة .

\section{اساليب تعلم المهارة:}

ان تعلم المهارات كما يراها هثام عبد السلام (107,2014 - 106) فى غاية

التعقيد ويتطلب شروطا مسبقة منها:

1. اكتساب المعلومات المتصلة بالمهارة من حيث الهدف والاجراءات ومن خلال ذلك يكتسب الطالب جميع المعلومات والمعارف المرتبطة بالجانب العملى للمهارة، وهنا يتم التعامل مع العمليات العقلية، مثل: الادراك، والملاحظة، والانتباه، وكذلك يلاحظ الطالب اداءاً عملياً للمهارة، كما يجب التركيز على الجوانب المهمة عند اداء المهارة. r. تجزئة المهارة الى مكوناتها الاساسية حيث من المفيد ان يتم تجزئة المهارة الى عدة اجزاء فرعية تكون فى مجملها المهارة الرئيسية وذلك يساعد على تعلم المهارة.

r. نقل السيطرة على التحكم بالمهارة من العين والدماغ الى الحواس الاخرى. ع. نقل اعتماد المهارة من العقل والحواس الى آليات التحكم. 0. نقل المهارة من الخبرة الثخصية الى التعميم. 


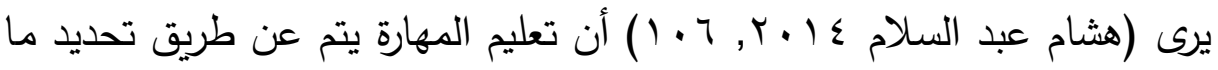

1. الأهداف الأدائية المنشودة وتحليلها إلى الأهداف السلوكية المكونة لها.

$$
\text { r. المهارات المرغوب فى تعلمها. }
$$

r. المتطلبات الأساسية لتعام المهارة.

ء. النشاطات والخبرات المكتسبة.

0. خطوات تنفيذ الخبرات لإكتساب المهارة.

7. طريقة تقويم تعلم المهارة وأدائها.

V. الأدوار والأجهزة والتسهيلات اللازمة لتعلم المهارة.

اهمية تعلم المهارات العملية فى التعليم الصناعى:

المهارة العملية فى اى عمل تيسره وتختصر وقته وتجعله اكثر اتقاناً ويعتمد طالب المدرسة الثانوية الصناعية على المهارة العملية عادة فى انجاز كثير من اعماله وفى القيام بانماط سلوكه اللازم لحياته اليومية والمهارة العملية ضرورية لنجاح العمل الذهنى والعمل اليدوى على السواء وعندما يجد طلاب المدرسة الثانوية الصناعية صعوبة فى تعلم شئ ما يكون من اهم اسباب ذلك عدم كفاية المهارة العملية الاساسية

$$
\text { التى لديهم (ممدوح عبد الناصر 62,2013). }
$$

ويمكن تحديد اهمية تنمية المهارات العملية فى التعليم الصناعى فيما يلى:

ا. ان اكتساب الطالب مهارات ما فى اداء عمل معين سوف يساعده على

العمل بكفاءة كبيرة، فبعض الاعمال تتطلب منها بعض المهارات مثل:

تثغيل الادوات والاجهزة وتركيبها واصلاحها وصيانتها مما يجعل الطالب

يسعى لاكتساب المهارات كى يتقن ما ينجزه من اعمال بذلك اصبح على 
تصميم برنامج إثرائى قائم على المعامل الافتراضية لتنمية مهارات أ.سماح محمد ناجى

اى فرد العمل على اكتساب الكثير من المهارات التى سوف تعود عليه بالمنفعة اثثاء تعلمه مهارات المواد المتخصصة لتمكنه من المهارات الضرورية اللازمة فى دراسته او فى مجال عمله او فى معيشته اليومية. r. تساعد المهارات العملية الطالب على مواجهة المشكلات التى قد تصادفه فى حياته فيتخذ القرارات العقلانية القائمة على اساس تقكيره الذاتى كما تكسب المهارات طالب المدرسة الثانوية الصناعية الميول الايجابية نحو تعلم المزيد من المهارات العملية فى التدرببات المهنية لمسايرة التقدم

$$
\begin{aligned}
& \text { التكنولوجى فى كافة المجالات الاخرى. } \\
& \text { أنواع المهارات العملية: }
\end{aligned}
$$

يمكن تصنيف المهارات العملية إلى عدة أنواع طبقًا للقائم بها وكذلك طبقًا

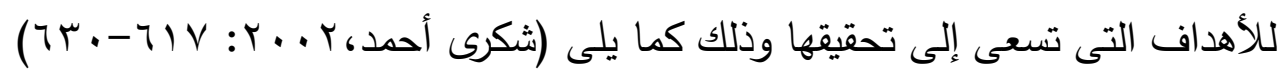
أ- أنواع المهارات العملية (من حيث القائم بها):

$$
\text { (1) (1) نشاط فردى: }
$$

يقوم الطالب بالنشاط بمغرده طبقًا لما هو مطلوب منه.

$$
\text { يستغرق وقتًا وجهدًا أقل. }
$$

\section{(Y) نشاط جماعى (مجموعات صغيرة):}

يقسم الطلاب إلى مجموعات صغيرة وتكلف كل مجموعة بأداء

$$
\text { مهمة أو مهام معينة. }
$$

يتم تقويم النشاط طبقًا لما ساهم به كل طالب فى النشاط.

(r) مشروع: (r)

يقوم به طالب واحد أو مجموعة طلاب. 
يحتاج تتفيذه إلى وقت وجهد كبيرين ويستغرق مدة زمنية أطول

$$
\text { (شهرمثلا أو شهرين). }
$$

ب - أنواع المهارات العملية من حيث أهدافها:

:Exploratory (1) (1)

تهدف لإتاحة الفرصة أمام الطالب لفحص الأجهزة والأدوات والتعرف على خصائصها إذا لم تكن مألوفة بالنسبة له.

\section{:Introductory تمهيدية (r)}

تهدف إلى تقديم الأفكار والمفاهيم عن طريق تداول الأدوات المحسوسة التى

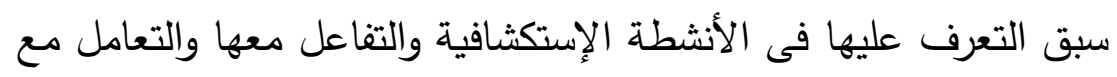
الموضوعات من خلال شكل عملى محسوس.

\section{:Developmental تطويرية}

تهدف إلى تثبيت أو تعزيز ما إكتببه الطالب خلال الأنشطة خلال الإستكشافية والتمهيدية ويمارسها الطالب بعد أن يكون قد اكتسب الفكرة

$$
\begin{aligned}
& \text { الأساسية ليبرهن على مدى فهمه لها. } \\
& \text { طرق تقوبم المهارات العملية: }
\end{aligned}
$$

يرى (محمد ابو هاشم، . . ץ: 100-109) هناك طريقتان يمكن استخدامهما

$$
\text { فى تقويم المهارات العملية هما: }
$$

لا تحتاج الطريقة الكلية إلى ملاحظة المتعلم أثناء أداء المهارة المراد تقويمها. ويكون المحك أو المعيار الذى يتم فى ضوئه الحكم أو التقويم على الإنتاج حيث يعتمد فى إصدار الأحكام على صحة الناتج النهائى للمتعلم

ومدى جودة العمل الذى قام به ومعدل الأداء فى الإنجاز • طبقًا لهذه الطريقة هناك ثلاث محكات للحكم على الأداء: 
تصميم برنامج إثرائى قائم على المعامل الافتراضية لتنمية مهارات أ.سماح محمد ناجى

صحة الناتج أو النتيجة المتوصل إليها.

جودة أداء العمل أو دقة الأداء.

معدل أداء العمل (السرعة)

ب- - الطربقة التحليلية:

تقوم هذه الطريقة على ملاحظة المتعلم أثناء أدائه المهارة العملية التى يراد تقويمها حيث يتم ملاحظة المتعلم خطوة بخطوة ويتطلب اتباع هذه الطريقة البدء بتحليل المهارة الى خطوات او انماط سلوك ينبغى على المتعلم ان يقوم بها أثناء

\section{معايير تقويم المهارات العملية:}

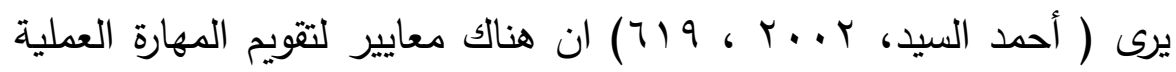

$$
\text { وكل معيار منها يخضع لمستوى الاتقان، وهذه المعايير هى: }
$$

1. الأداء: ويتم التأكد من قيام المتعلم بتنفيذ خطوات المهارة بالشكل المطلوب ، بحيت تؤدى هذه الخطوات الى الوصول للأداء الصحيح للمهارة.

r. الأستتتاج: حيث يتم التأكد من قيام المتعلم باستتتاج ما يمكن حدوثه ، نتيجة قيامه بخطوات هذه المهارة.

r. التفسير: يقدم المتعلم تعليلاً مناسباً لما يحدث ويراه نتيجة قيامه بخطوات هوهات أداء المهارة فى ضوء ما سبق استتتاجه ويقدم تفسيراً عملياً منطقياً. ع. التقدير: ويشمل تقدير الطول ، والمسافة ، والزمن ، والاحجام ، والسعات ، والاوزان ، والكميات الكهربية. 


\section{إعداد أدوات البحث وطريقة ضبطها}

\section{الأداة وطريقة ضبطها:}

تم تصميم اد|تين لهذه الدراسة وهما:

الأداة الأولى: الاختبار التحصيلى المعرفى

في ضوء قائمة الأهداف التعليمية ، والمحتوى التعليمي ، و قائمة المهارات للبرنامج المقترح, قامت الباحثة بتصميم وبناء اختبار التحصيلي معرفى يتتاول الجانب المعرفي للمهارات العلملية, وقد مر الاختبار في إعداده بالمراحل التالية : ا ـ تحديد الهدف من الاختبار:

يهدف هذا الاختبار الى قياس مستوى الطالب فى الجانب المعرفى

لمعرفة مدى اكتساب طلاب الصف الاول الصناعى نظام الثلاث سنوات تخصص الكترونيات - للمفاهيم والمعلومات المعرفية المتضمنة بالوحدة التجربية ومدى تحقيقهم لاهداف الوحدة التجربية.

r. تحديد مستويات التعلم المعرفية التى يتضمنها الاختبار التحصيلى المعرفى:

$$
\begin{aligned}
& \text { اشتمل هذا الاختبار على مستويات الاهداف المعرفية وهى: } \\
& \text { مستوى التذكر: }
\end{aligned}
$$

وهو القدرة على تذكر او استرجاع المفاهيم والمعلومات والمصطلحات المتضمنة بالوحدة التجربية.

\section{مستوى الفهم:}

وهو يعنى إدراك المعانى واستيعاب ما يدرسه الطالب من مفاهيم

ومعلومات ثم القدرة على صياغتها بلغته الخاصة. 
تصميم برنامج إثرائى قائم على المعامل الافتراضية لتنمية مهارات أ.سماح محمد ناجى

\section{مستوى التطبيق:}

وهو يعنى قدرة الطالب على استخدام المفاهيم والمعلومات والمصطلحات الجديدة التى تم تعلمها بالوحدة التجربية لحل مشكلات فى مواقف جديدة مشابهاه وغير مألوفة. مستوى التحليل:

وهو يعني القدرة على تحليل العناصر ومكونات الخبرة او الموقف وبيان العلاقة بين فيما بينها والتى يمر بها الطالب اثناء اداء المهارات العملية المتضمنة بالوحدة التجربية.

1. تحديد الاوزان النسبية لمستويات التعلم (جدول المواصفات): تم إعداد جدول مواصفات للاختبار ، وذلك للربط بين الأهداف التعليمية للبرنامج وبين المحتوى المعرفي للبرنامج التجريبي المقترح وما يتضمنه من مهارات عملية ، كما يوضحه الجدول التالي:

\begin{tabular}{|c|c|c|c|c|c|c|}
\hline \multirow{2}{*}{ للاهداف النسبي } & \multirow{2}{*}{ الكلى للاسئلة } & \multicolumn{4}{|c|}{ المستويات المعرفية } & \multirow{2}{*}{ الوحدة التجريبيةت التعلم } \\
\hline & & التحليل & تطبيق & فهم & ت تذكر & \\
\hline$\% 100$ & 64 & 10 & ir & r. & rr & الوحدة الاولى \\
\hline$\%$ & 64 & 10 & 12 & 20 & 22 & عدد المفردات \\
\hline$\% 1 \ldots$ & 一 & $17 \%$ & $19 \%$ & $30 \%$ & $\%$ & الاوزان النسبية \\
\hline
\end{tabular}

جدول (ع) الاوزان النسبية ومواصفات الاختبار التحصيلي لمستويات التعلم r . وضع وصياغة اسئلة الاختبار التحصيلى: تم صياغة مفردات الاختبار في صورته المبدئية في (عاب) سؤال موزعة على

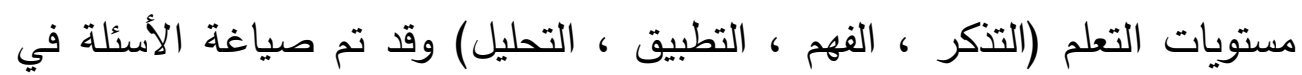
اربعة أجزاء : 
الجزء الاول: أسئلة الاختيار من متعدد: عدد مفرداتها (7 ( ) مفردة ،

مصاغة في عبارة تشتمل على المثير ( المهارة ) ، واربع بدائل للإجابة ، من بينهم بديل واحد يمثل الإجابة الصحيحة.

الجزء الثانى: أسئلة اختر من المجهوعة (أ) ما يناسبها من المجموعة (ب): وعدد مفردتها (7 ( ) مفردة.

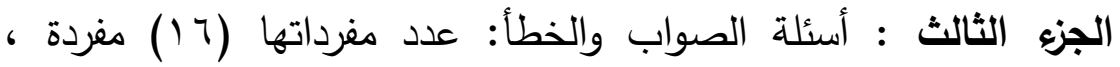
مصاغة في عبارة ، على الطالب أن يضع علامة ( ل ) إذا كانت العبارة صحيحة وعلامة (×) إذا كانت العبارة خاطئة مع تصحيح الخطأ. الجزء الرابع: أسئلة اكمال العبارات المصورة بما تراه مناسب: عدد مفرداتها (7 (1) مفردة ، على الطالب ان يكمل العبارات بما يراه مناسب فى المكان المخصص لذلك.

\section{وتم إعداد نسختين من الاختبار التحصيلي:}

r. النسخة الأولي : استخدمت في الاختبار القبلي الذي يتم تقديمه قبل التعامل مع البرنامج التجريبي لقياس الخلفية المعرفية السابقة المتوفرة لدى الطلاب في المحتوى التعليمي لمهارات "تكوين الدوائر الالكترونية" . . ء. النسخة الثانية: استخدمت في الاختبار البعدي الذي تم تقديمه بعد الانتهاء من التدريب على البرنامج. وتم وضع الاختبار نفسه كإختبار بعدى ، بحيث يستخدمه الطالب بعد الانتهاء من دراسة محتوي البرنامج ، ويجيب على الطالب أن يقرأ التعليمات الخاصة بالإجابة علي الاختبار جيداً قبل البدأ فى الاجابة على وبى

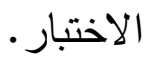


تصميم برنامج إثرائى قائم على المعامل الافتراضية لتنمية مهارات أ.سماح محمد ناجى

๑. تحيد تعليمات الاختبار: تم ارفاق التعليمات الخاصة بالاجابة على الاختبار مع ورقة الاختبار ، وروعى فيها ان تكون محددة بدقة واضحة وبسيطة والتعليمات كانت كالاتى:

1. كتابة بياناتك كاملة وواضحة فى المكان المخصص لذلك. r. ابدأ بالاختبار فور السماح لك بهذا. r. اقرأ السؤال جيداً قبل البدأ فى الاجابة عليه. ع. اكتب اجابتك فى المكان المخصص لذلك جلك ه. لا تترك اى سؤال دون الاجابة عليه. 7. لا تكتب اكثر من اجابة على كل سؤال.

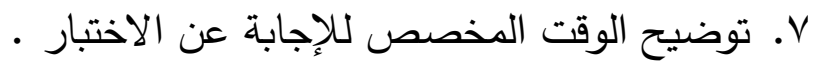
7 .

وتم استخدام صدق المحتوى أو الصدق الظاهري للاختبار وذلك بعرضه على مجموعة من المحكمين في صورة استبيان بغرض استطلاع آرائهم فيما يلي: مدى ملائمة الاختبار لأهداف البرنامج •

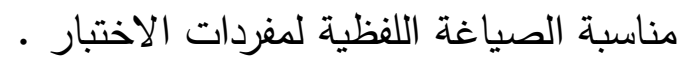
مدى مناسبة الاختبار لما اعد لقياسه. سلامة صياغة مقدمة كل سؤال ومدى اتساق البدائل .

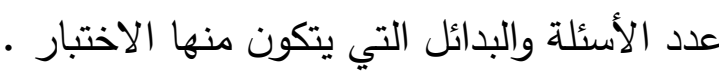
مدى كفاية بنود الاختبار لما اعد له.

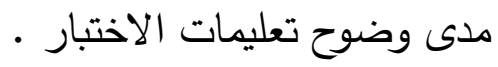

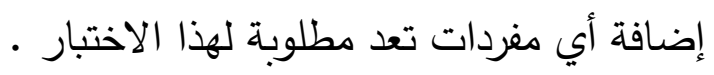
حذف أي مفردات غير مناسبة من وجهة نظرهم • وفى ضوء أراء السادة المحكمين تم إجراء العديد من التعديلات من أهمها : 
تعديل صياغة بعض مفردات الاختبار ، حذف بعض الكلمات المكرة ، وبعد الانتهاء من إجراء التعديلات وفق ما اتفق عليه السادة المحكمون ، تم إعداد الاختبار التحصيلي في صورته النهائية(* ) الذي يقيس الجانب المعرفي المرتبط بمهارات تكوين الدوائر الالكترونية .

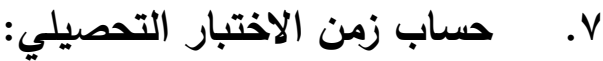

تم تطبيق الاختبار التحصيلى على عينة من طلاب الصف الاول الثانوى الصناعى بمدرسة السلحدار الثانوية الصناعية بنات - تخصص الكترونيات (دون عينة البحث) ، وقد بلغ عدد العينة ( ro ) طالبة و تم حساب زمن الاختبار عن طريق تحديد الزمن الذي استغرقه طلاب العينة الاستطلاعية

$$
\text { مقسوماً على عدد العينة. }
$$

$$
\text { الزمن = = مجموع الأزمنة للطلاب }
$$

تم حساب الزمن الكلى للاختبار وذلك بحساب الزمن الذى استغرقته اول طالبة فى الانتهاء من الاختبار (Y I I) دقيقة ، وكان الزمن الذى استغرقته اخر طالبة فى الانتهاء من الاختبار (•r (1) دقيقة من خلال تطبيق المعادلة السابقة تم حساب الوقت اللازم للاختبار وهو ( ( I I ) دقيقة وبما ان هناك تعليمات لابد للطالبة ان تقرأها قبل الاجابة على الاختبار تم تعديل زمن الاختبار ليصبح ( ـا م ) دقيقة. ^. حساب ثبات الاختبار التحصيلي:

المقصود بثبات الاختبار هو ان يعطى الاختبار نفس نتائج الاختبار الاول اذا ما اعيد تطبيقه على نفس العينة ، وفى نفس الظروف. وللتأكد من ثبات الاختبار التحصيلي المعرفى تم تطبيق الاختبار على نفس عينة الدراسة الاستطلاعية ، ثم اعيد تطبيق نفس الاختبار على نفس العينة الاستطلاعية ، تحت نفس الظروف 
تصميم برنامج إثرائى قائم على المعامل الافتراضية لتنمية مهارات أ.سماح محمد ناجى

وعلى نفس العينة بفاصل زمنى قدره اسبوعين ، وتم رصد الدرجات التى حصل عليها الطالبات فى التطبيقين ، ثم تم استخدام معادلة (بيرسون) لحساب معاملات الارتباط (معاملات الثبات) وذلك بهدف قياس ثبات الاختبار فكان معامل الثبات هو ( AV, • ) وهذه النتيجة مناسبة ةتدل على ثبات الاختبار ، وبهذا يصبح الاختبار التحصيلي فى صورته النهائية (**) صالح للتطبيق بعد التأكد من صدق الاخته الاختبار وثباته.

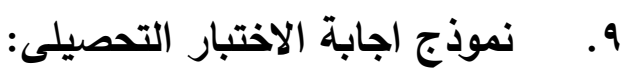

تم اعداد نموذج تصحيح الاختبار التحصيلي المعرفى لاستخدامه فى تقدير

$$
\text { درجات الطالبات ومرفق به جدول يوضح درجات كل سؤال على حده. }
$$

تطلب البحث الحالي إعداد بطاقة ملاحظة لقياس المهارات المرتبطة بتكوين

$$
\begin{aligned}
& \text { الدوائر الالكترونية ، وتم بنائها وفق الخطوات التالية: } \\
& \text { أ- تحديد هدف بطاقة الملاحظة. } \\
& \text { ب- تحديد مكونات بطاقة الماحظة } \\
& \text { ت- تحديد محتوى بطاقة الملاحظة. } \\
& \text { ث- وضع نظام تقدير الاداء. }
\end{aligned}
$$

ج- التحقق من صدق بطاقة الملاحظة.

ح- حساب ثبات بطاقة الملاحظة.

\section{أ- ت تحديد هدف بطاقة الملاحظة:}

تهدف إلى الحصول على مقياس صادق وثابت بدرجة مطمئنة لقياس مستوى أداء طلاب عينة البحث لمهارات تكوين الدوائر الآكترونية المتضمنة في البرنامج المقترح وقياس درجة نمو الاداءات المهارية لديهم فى المهارات العملية

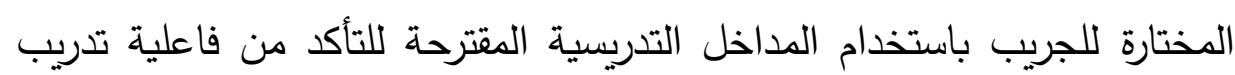
الوحدة المختارة للتجريب. 


\section{ب- تحديا مكونات بطاقة الملاحظة:}

تحتوى بطاقة الملاحظة على بيانات كل طالب ، والمهارات العملية الرئيسة

$$
\text { ، والمهارات الفرعية المكونة لكل مهارة رئيسية. }
$$

لقد اشتملت الوحدة التجربية على اربع بطاقات ملاحظة ، لاربع مهارات رئيسية ، وتضمنت كل مهارة رئيسية عدد من المهارات الفرعية(*) وقد روعى فى دي بطاقة الملاحظة ما يلى:

أن تقيس كل عبارة سلوكا محددا و واضحا. أن تبدأ العبارات بفعل سلوكى فى زمن المضارع. احتوائها على مستويات الأداء الذي سيتم ملاحظته. عدم اشتمال العبارة على أكثر من أداء. أن تتيح للملاحظ تسجيل الأداء فور حدوثه حتى لا يختلط بالأداء التالي أو السابق ن

$$
\text { د -وضع نظام تقدير الاراجات: }
$$

تم استخدام أسلوب التقدير الكمي بالدرجات للتوصل إلى معرفة مستويات أداء الطالبات لكل مهارة من مهارات تكوين الدوائر الآكترونية ،

$$
\text { وقد تم تحديد ثلاثة مستويات لأداء الطالب وهى: }
$$

• أداء كل مهارة من المهارات بشكل صحيح وبكفاءة يقدر (بدرجتين).

أداء كل مهارة من المهارات بدرجة مقبولة يقدر (بدرجة واحدة) .

أداء كل مهارة من المهارات بطريقة خاطئة أو تركه لها يقدر (بصفر) . وقد بلغت القيمة الوزنية بالدرجات لكل مهارة من مهارات تكوين الدوائر الالكترونية (ء ا درجة) وهى قيمة الأداء الصحيح لجميع خطوات أداء المهارات 
تصميم برنامج إثرائى قائم على المعامل الافتراضية لتنمية مهارات أ.سماح محمد ناجى والتي بلغ عددها (rr مهارة) ، وبذلك تكون مهمة ملاحظ الأداء هي ملاحظة الطالبة في أدائها لكل خطوة من خطوات المهارة ، ووضع علامة ( ل ) في مهات الخانة المحددة لمستوى الأداء ( ادى المهارة بكفاءة - ادى المهارة بدرجة مقبولة - لم يؤدى المهارة ) كما يلي:

\begin{tabular}{|c|c|c|c|}
\hline الدى المهارة بكفاءة الثالث & المقى المستوى الثانى & لم يؤدى المهارة الاول & مستويات التقدير \\
\hline r & 1 & . & الدرجة \\
\hline
\end{tabular}

$$
\begin{aligned}
& \text { جدول ( 0 ) يوضح مستويات تقدير بطاقة الملاحظة } \\
& \text { هـ - التحقق من صدق بطاقة الملاحظة. }
\end{aligned}
$$

تم حساب الصدق الظاهري لبطاقة الملاحظة والذي يتضمن المظهر العام للبطاقة من حيث ( نوع المغردات ، كيفية صياغتها ، وضوحها ، دقتها ، موضوعيتها ) ، وذلك بعرضه على مجموعة من المحكمين في صورة استبيان بغرض استطلاع آل

$$
\text { آرائهم في : تحنة }
$$

تحقيق بنود بطاقة الملاحظة للأهداف التعليمية .

صحة تحليل المهارة وتسلسلها واكتمالها .

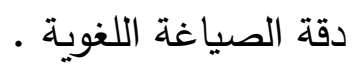

درجة أهمية المهارات الفرعية بالنسبة للمهارات الرئيسية .

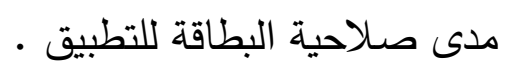

التعديل بالإضافة أو الحذف للمهارات التي ترونها سيادتكم .

وقد اتفق معظم السادة المحكمون على تعديل صياغة بعض مهارات بطاقة الملاحظة ، وتدقيق صياغة بعضها، حذف بعضها الآخر ، وبعد الانتهاء من إجراء 
التعديلات وفق ما اتقق عليه معظم السادة المحكمون ، تم إعداد البطاقة في صورتها النهائية* بعد ان تأكد صدق بطاقة الملاحظة . و - حساب ثبات بطاقة الملاحظة.

ولحساب ثبات البطاقة تم توزيع بطاقة الملاحظة - بعد مرور اسبوعان من عملية التحكيم على صدق البطاقة للمرة الاولى - على نفس المحكمين ، لحساب صدق البطاقات ، ثم تم حساب نسبة اتفاق السادة المحكمين* باستخدام معادلة "كوبر" ، وفقا للمعادلة التالية :

$1 \ldots x$ عدد الخطوات المتفق عليها نسبة الاتفاق = عدد الخطوات المتفق عليها + عدد الخطوات غير المتفق عليها

من خلال هذه المعادلة تم حساب نسبة الاتفاق بين السادة المحكمين وقد بلغت النسبة ( V0, • 9 ) مما يعنى أنها ثابتة إلى حد كبير ، وبالتالى اصبحت البطاقة فى صورتها النهائية صالحة للتطبيق على العينة المستهدفة للبحث بعد التأكد من صدق وثبات بطاقة ملاحظة العمل المهارى. التجربة الإستطلاعية للوحدة التدربسية: بعد تصميم الوحدة التدريسية ودروسها بناء على التخطيط العام للبرنامج ، وبعد الإنتهاء من إعداد أدوات البحث ، تم تطبيق هذه الوحدة إستطلاعيًا على عينة من طلاب الصف الأول الثانوى الصناعى نظام الثلاث سنوات - تخصص الإلكترونيات - دون عينة البحث وعددهم ( P ) طالبة وقد تم التطبيق بمدرسة السلحدار الثانوية الصناعية بنات - تخصص الإلكترونيات - التابعة لإدارة مصر الجديدة التعليمية.

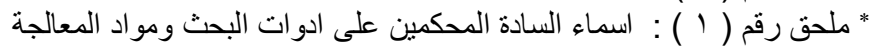


تصميم برنامج إثرائى قائم على المعامل الافتراضية لتنمية مهارات أ.سماح محمد ناجى

\section{تهدف التجربة الإستطلاعية الى:}

التعرف على الصعوبات التى قد يقابلها الباحث فى اثناء تطبيق تجربة

$$
\text { البحث ومحاولة إيجاد حلول لها. }
$$

التعرف على نواحى القوة لتدعيمها ونواحى الضعف لتلاشيها ـ

ضبط ادوات البحث (الختبار التحصيلى - بطاقة ملاحظة الاداء المهارى)

اكتساب خبرة من التطبيق الاستطلاعى لضمان إجراء التجربة الأساسية

بكفاءة.

\section{وقد اتبعت الباحثة الخطوات التالية:}

ا ـ تجهيز معمل الحاسب الالى والتأكد من اتصاله بالانترنت.

$$
\text { r. تدريس الوحدة التجريبية ودروسها. }
$$

تطبيق أدوات البحث (الإختبار التحصيلى - بطاقة الملاحظة ).

$$
\text { نتائج البحث: }
$$

توصل البحث الى النتائج التالية:

ا. يوجد فرق ذو دلالة احصائية عند مستوى( (.,.) بين متوسطى درجتى طلاب المجموعة التجريبية والمجموعة الضابطة فى إختبار التحصيل المعرفى قبل وبعد تطبيق البرنامج الإثرائى القائم على المعامل الافتراضية لصالح طلاب المجموعة التجربية فى الاختبار البعدى. r. يوجد فرق ذو دلالة احصائية عند مستوى( (.,.•) بين متوسطى درجتى طلاب المجموعة التجريبية والمجموعة الضابط فى بطاقة ملاحظة الاداء المهارى قبل وبعد تطبيق البرنامج الإثرائى القائم على المعامل الافتراضية لصالح المجموعة التجريبية فى الاختبار البعدى. 
ץ. توجد علاقة ارتباطية موجبة بين متوسطى درجات طلاب المجموعة التجربية فى نمط التدريس القائم على المعامل الافتراضية بالبرنامج الإثرائى المقترح. ء. توجد علاقة ارتباطية موجبة بين متوسطى درجات طلاب المجموعة

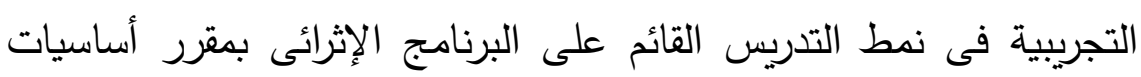
الهندسة الكهربية وتتمية مهارات تكوين الدوائر الالكترونية.

\section{توصيات الدراسة}

في ضوء ما توصلت إليه الدراسة من نتائج، فإن الدراسة تقدم مجموعة من التوصيات التي يمكن أن تسهم في واقع تطوير العملية التربوية والتعليمية لطلاب التعليم الصناعي، من خلال استخدام البرنامج الاثرائي القائم علي المعامل الافتراضية، والتي تهدف إلي تتمية مهارات تكوين الدوائر الكهربائية لطلاب المرحلة الثانوية، وتتمثل هذه التوصيات فيما يلي:

1. استخدام المعامل الافتراضية في دعم العملية التعليمية لمقرر أساسيات الهندسة الكهربية لتحقيق أهدافها، وتقديمها في صورة متطورة للطلاب، بصورة تحقق تفاعلهم مع ما يقدم لهم من خبرات. r. الإستفادة من تقنية المعامل الإفتراضية لتجاوز المشكلات والعوائق التى تواجه المعلمين والطلابفى تفعيل الجانب العملى فى دراسة أساسيات المهندسة الكهربية.

r. تتظيم دورات تدريبية لمعلمي التعليم الصناعي على تصميم التدريس باستخدام البرنامج الاثرائي القائم علي المعامل الافتراضية ء. اهتمام القائمين على الادارة العامة لتطوير المناهج بضرورة تصميم برامج قائمة علي المعامل الافتراضية بجميع مراحل التعليم المختلفة. 
تصميم برنامج إثرائى قائم على المعامل الافتراضية لتنمية مهارات أ.سماح محمد ناجى

0. الأستفادة من خبرات الدول التى طبقت هذه التقنية بشكل ناجح وذلك

باختيار بعض البرامج وترجمتها ومن ثم تطبيقها فى المدارس.

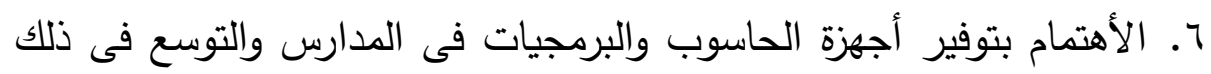

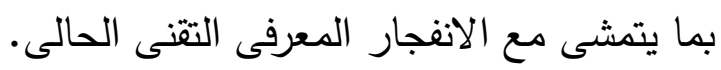

V. إنثاء موقع للمعامل الإفتراضية على الثبكة العالمية للإنترنت بما يتيح

استفادة المعلمين والطلاب من هذه التقنية.

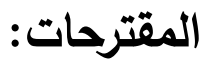

ا. إجراء دراسات حول أثر إستخدام تقنية المعامل الإفتراضية على بعض

الفئات الخاصة المتفوقين أو المتأخرين دراسيًا.

r. إجراء دراسة مسحية تبين اتجاهات المعلمين والطلاب نحو المعامل الإفتراضية.

r. إجراء دراسة لبيان أثر استخدام المعامل الإفتراضية على التحصيل فى مواد

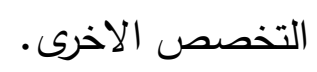

ع. إجراء دراسات تبين أثر استخدام المعامل الإفتراضية فى تدريس طلاب كلية

التعليم الصناعى وكلية التربية تخصص تعليم صناعى. 


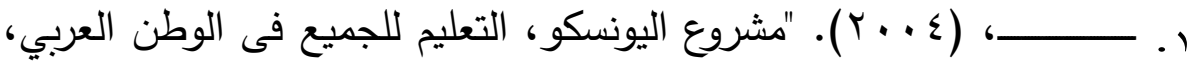

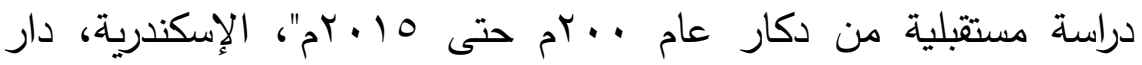

الوفاء.

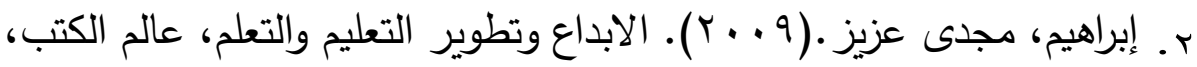

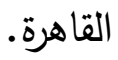

r. إحسان الأغا، محمود الأستاذ ( . . . البحث التربوى عناصره، مناهجه،

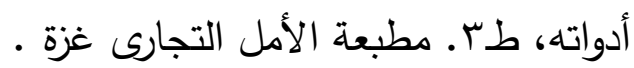

ع. احمد اسماعيل حجى. (ع . . ץ). تطوير التعليم فى زمن التحديات الأزمة وتطلعات المستقبل. (ط ا ). القاهرة. النهضـة المصرية.

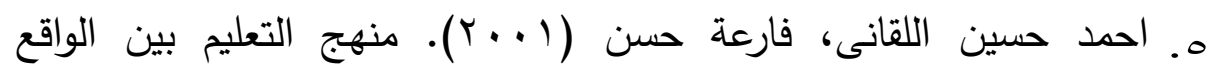
والمستقبل. القاهرة، عالم الكتاب، القاهرة.

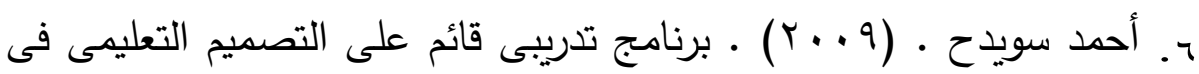

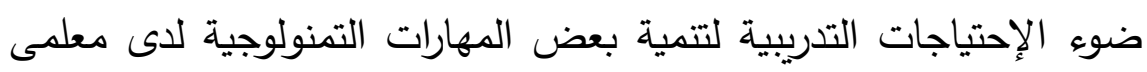
التكنولوجيا. رسالة ماجستير كلية التربية الجامعة الإسلامية غزة. v. أروى وضاح.(9 . . ؟). أثر برنامج مقترح في ضوه الكفايات الالكترونية لاكتساب بعض مهارات لدى طالبات تكنولوجيا التعليم في الجامعة الإسلامية. بفلسطين رسالة ماجستير ـ كلية التربية الجامعة الاسلامية.

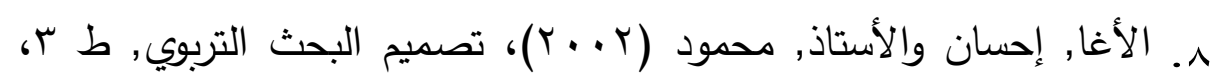

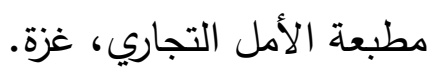
9. بسيوني ، عبد الحميد ( ^ . . r ) • التعلم الإلكتروني والتعليم الجوال . القاهرة: دار الكتب العلمية للنشر والتوزيع 


\section{تصميم برنامج إثرائى قائم على المعامل الافتزاضية لتنمية مهارات أ.سماح محمد ناجى}

• . . البلطان، ابراهيم عبدالله سليمان (1) (1) استخدام المعامل الافتراضية في

تدريس العلوم بالمرحلة الثانوية في المملكة العربية السعودية : الواقع وسبل

$$
\text { التطوير بحث مكمل لرسالة ( الدكتوراه ) - جامعة ام القرى. }
$$

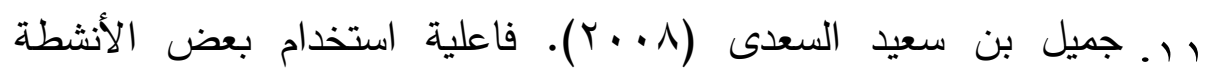
الإثرائية القائمة على اساليب استشراق المستقبل فى تدريس مادة التاريخ بالتعليم العام بسلطنة عمان فى تتمية مهارات التفكير المستقبلى. رسالة دكتوراه. معهد البحوث والدراسات التربوية. جامعة القاهرة.

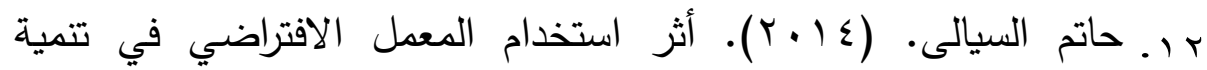
المهارات العملية لدى طلاب مادة العلوم للصف الاول متوسط. رسالة ماجستير . كلية التربية. جامعة ام القرى.

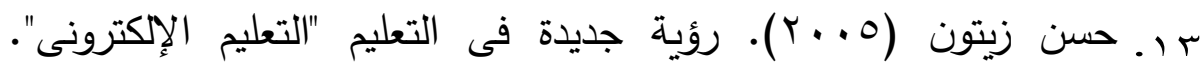
المفهوم - القضايا - التطبيق - التقييم. الدار الصولتية للنشر والتوزيع.

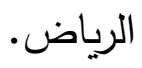
ع 1. الحيلة، محمد (1 . . ب) التكنولوجيا التعليمية والمعلوماتية. الإمارت العربية المتحدة ـ دار الكتب الجامعى. ه ـ دينا صابر r ا • r: أثر تطوير وحدة الإلكترونيات بمبحث التكنولوجيا في ضوء المعايير العالمية في تنمية المهارات الإلكترونية لدى طالبات الصف العاشر الأساسي بغزة رسالة ماجستير كلية التربية الجامعة الاسلامية.

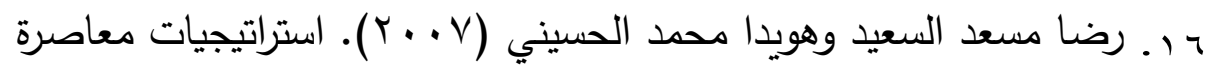
فى التدريس للموهوبين والمعوقين، مركز الإسكندريـة للكتاب، الإسكندرية. V ا. الزامل،زكريا بن عبدالله (T + . ץ). اتجاهات الطلاب نحو تجربة التعليم الالكترونى فى مؤسسة العامة للتعليم الفنى والتدريب المهنى والجامعة 
العربية المفتوحة بالرياض. مجلة الملك سعود. م 1 1. العلوم التربوية

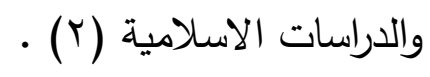

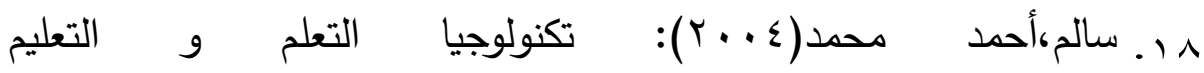
الألكتروني،الرياض،مكتبة الرشد.

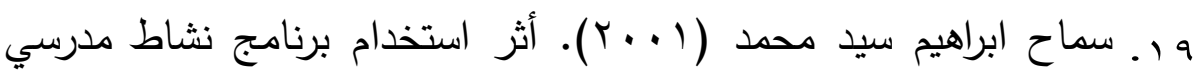
لتدريس التاريخ للصف الخامس الابتدائى على تتمية بعض المفاهيم السياسية، رسالة ماجستير غير منشورة، كلية التربية، جامعة عين شمس.

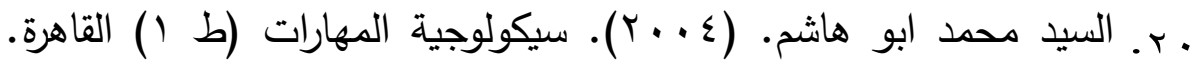

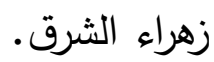

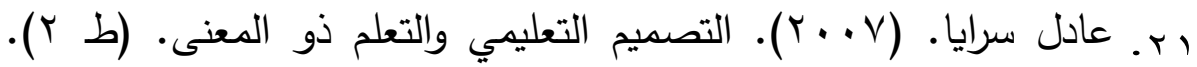

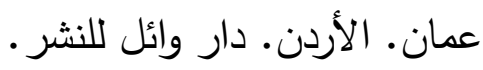
r. عادل صلاح. (111) (Y). فاعلية برنامج لتنمية مهارات مقرر صيانة السيارات لدى طلاب المدارس الثانوية الصناعية فى ضوء المستحدثات التكنولوجية. رسالة ماجستير • كلية التربية. جامعة حلوان. r.. عادل صلاح. (111). (Y). فاعلية برنامج لتنمية مهارات مقرر صيانة السيارات لدى طلاب المدارس الثانوية الصناعية فى ضوء المستحدثات التكنولوجية. رسالة ماجستير • كلية التربية. جامعة حلوان.

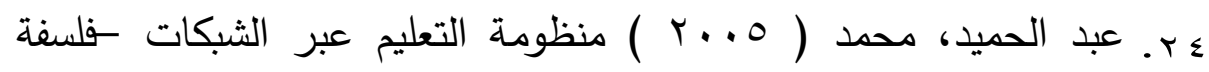
التعلم الإلكتروني عبر الشبكات، الطبعة الأولى، القاهرة: عالم الكتب.

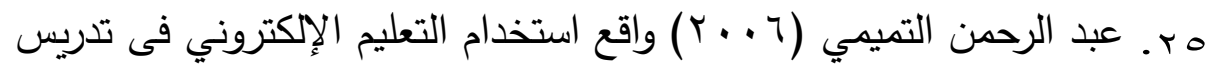
الرياضيات بالمرحلة الثانوية فى ضوء معايير NCTM ببعض الدول المختارة. رسالة دكتوراه غير منشورة. جامعة الأسكندرية. مصر . 


\section{تصميم برنامج إثرائى قائم على المعامل الافتراضية لتنمية مهارات أ.سماح محمد ناجى}

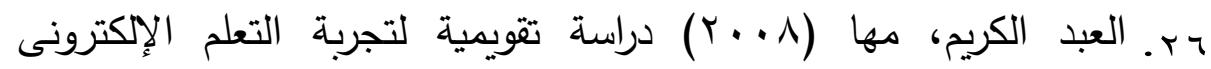
بمدارس البيان النموذجية للبنات بجدة. رسالة ماجستير غير منشورة. جامعة الملك سعود. كلية التربية. الرياض.

V. للتعليم والتدريب الإكترونى.

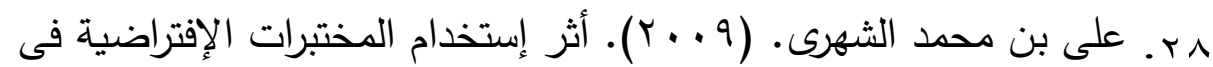
إكساب مهارات التجارب المعملية فى مقرر الأحياء لطلاب الصف الثالث الثانوى بمدينة جدة. رسالة دكتوراه كلية التربية. جامعة أم الترى.

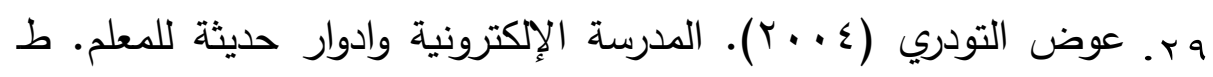

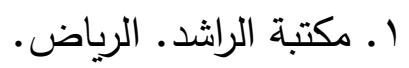

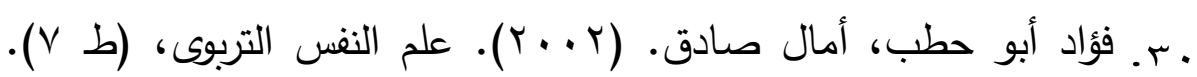
القاهرة. مكتبة الأنجلو المصرية.

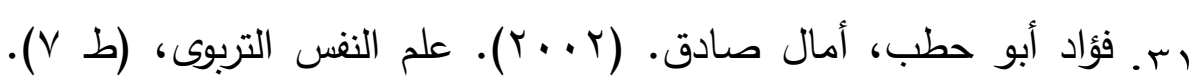
القاهرة. مكتبة الأنجلو المصرية. r.r. القبالي، يحيى أحمد عبد الرحمن (9 . . Y)، فاعلية برنامج إثرائي قائم على الألعاب الذكية في تطوير مهارات حل المشكلات والدافعية للإنجاز لدى الطلبة المتفوقين في السعودية. رسالة ماجستير • جامعة عمان العربية للدراسات العليا كلية الدراسات التربوية العليا. rr. محسن العبادي.(r . •rم),التعليم والتعليم التقليدي ماهو الاختلاف,

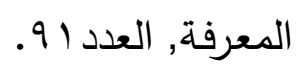

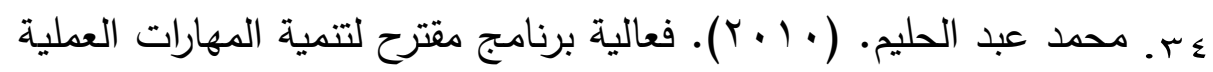
لطلاب المدرسة الثانوية الصناعية - تخصص سيارات - فى ضوء متطلبات سوق العمل. رسالة ماجستير • كلية التربية. جامعة حلوان. 
هـ. محمد عطية خميس (T . . ץ). منتجات تكنولوجيا التعليم. طا ـ مكتبة دار الكلمة. القاهرة. - ماه.

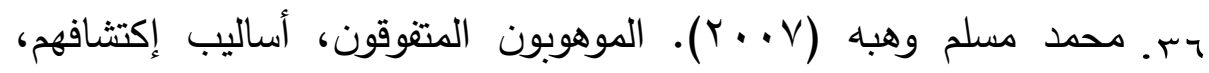
ورعايتهم. دار الوفاء لدنيا الطباعة والنشر ، الأسكندرية. V.r. المركز القومي للتعليم الإلكتروني بالمجلس الأعلى للجامعات( • • ؟ ). دليل إرشادي ونموذج التقدم لطلب إتاحة معمل افتراضي للمقررات العلمية

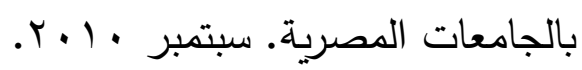

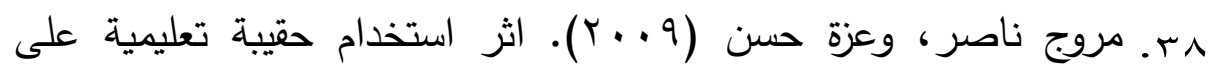
التحصيل الدراسي في مقرر الالكترونيات لدى طلاب كلية بور تسودان التقنية. ورقة بحثية منشورة على موقع الاكاديمية العربية البريطانية للتعليم

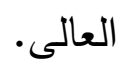

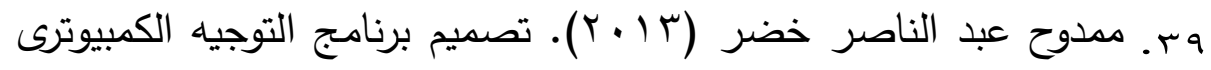
لتمية بعض المهارات التدريبات المهنية لدى طلاب الشعب الكهربائية بالتعليم الصناعى وقياس فاعليته. رسالة ماجستير . كلية التربية. جامعة حلوان. • ع. منى هادى صالح. (T/ • (Y). دراسة امكانية تطبيق بيئة تعليم افتراضية في المؤسسات التعليمية. مجلة كلية بغداد للعلوم الاقتصادية الجامعة العدد الخاص بمؤتمر الكلية. العراق

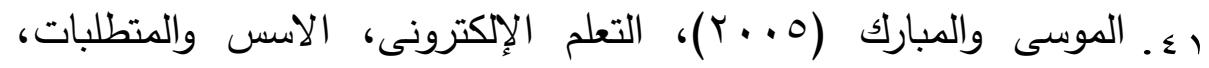
الرياض. مؤسسة شبكة البيانات. r ـ نجلاء خلاف. (10 1 ب). فاعلية برنامج مقترح للتدريبات المهنية فى تتمية المهارات العملية لدى طلاب المدرسة الفنية المتقدمة الصناعية (تخصص 


\section{تصميم برنامج إثرائى قائم على المعامل الافتزاضية لتنمية مهارات أ.سماح محمد ناجى}

النسيخ) وفقًا لمتطلبات سوق العمل. رسالة ماجستير • كلية التربية. جامعة

حلوان.

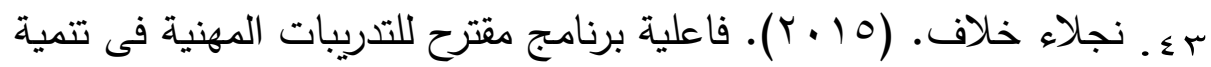

المهارات العملية لدى طلاب المدرسة الفنية المتقدمة الصناعية (تخصص النسيخ) وفقًا لمتطلبات سوق العمل. رسالة ماجستير • كلية التربية. جامعة حلوان.

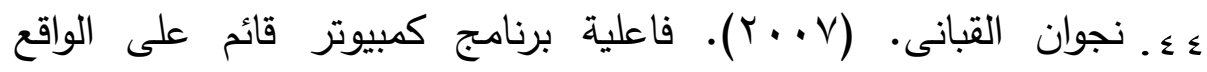
الإفتراضى فى تتمية القدرة على التفكير والتخيل البصرى وفهم بعض العمليات والمفاهيم فى الهندسة الكهربية لدى طلاب التعليم الصناعى. رسالة دكتوراه غير منشورة. كلية التربية. جامعة الأسكندرية. 0ـ. نصر محمد محمود (؟ . . Y). استخدام اسلوب النظم فى التخطيط لتربية ورعاية الموهوبين فى مصر فى ضوء بعض الاتجاهات العالمية المعاصرة،

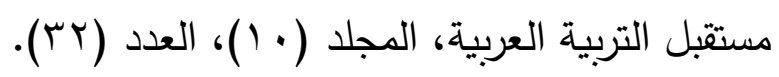

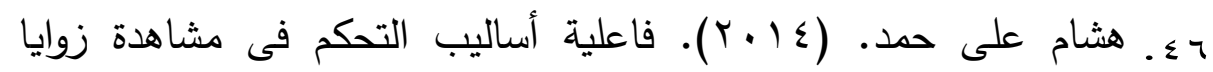
التصوير ببرامج الكمبيوتر التعليمية فى إكساب طلاب التعليم الصناعى مهارات إنتاج الدوائر الإلكترونية. كلية التعليم الصناعى. جامعة حلوان.

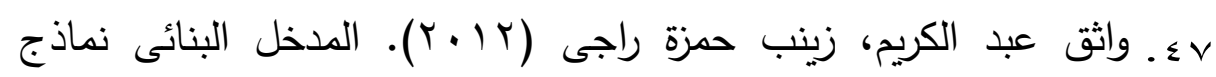
واستراتيجيات فى تدريس المفاهيم العلمية. طا ا، مكتبة نور الحسين بغداد.

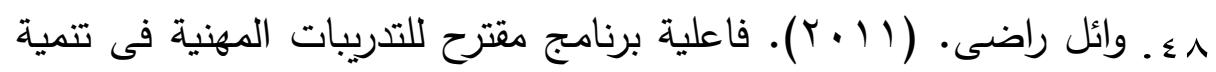
مهارات المنتج الفنى لدى طالبات المدرسة الثانوية الصناعية الزخرفية. دراسات عربية فى التربية وعلم النفس. جزء ثانى. العدد الثامن والعشرين.

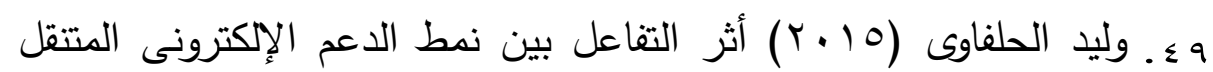
والأسلوب المعرفى فى تتمية التحصيل وبقاء اثر التعلم لدى طلاب 


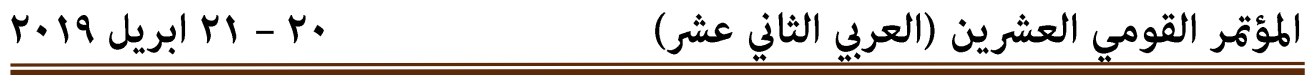

الدراسات العليا. ورقة عمل مقدمة للمؤتمر الدولى الرابع للتعليم الإلكترونى.

$$
\text { الرياض. }
$$

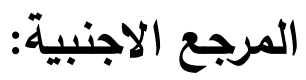

1. Carnevale, D.(2003). the Virtual lab experiment some colleges use computer to expand science offerings online. The Chronicle of Higher education, 49, (21), 30 - 32 .

2. Change, Chun-Yen(2002) Dose Computer-Assisted Instruction + Problem Solving $=$ Improved Science Outcomes? Apioneer Study. Journal of Education Research,95,(3),143-150 .

3. Dalgarno,b; Bishop,A \& Bedgood Jr,D (2003) : The Potential of Virtual Laboratories for Distance Education Science teaching : Reflections from The Development and Evaluation of a Virtual Chemistry Laboratory , Uni Serve Science Improving Learning Outcomes Symposium Proceeding, Charles Sturt University ,90-95 .

4. Dillon ,s,(2007):Virtual Science Labs . New York Times Upfronrt ,feb,193,10, Research Library , 26 .

5. Jensen, N.; Voigt, G.; Nejdl, W. \& Olbrich, S. (2004) "Development of a Virtual Laboratory System for Science Education" Interactive Multimedia Electronic Journal of Computer-Enhanced-Learning:

http://imej.wfu.edu/articles/2004/2/03/index.asp 
تصميم برنامج إثرائى قائم على المعامل الافتراضية لتنمية مهارات أ.سماح محمد ناجى

6. Smith, L., Bock, M., farrow, K., Gerardy, N.(2004).A Guide for Developing Gifted Curriculum Documents. Colombia, Missouri. Retrieved.

7. Woodfield, B.F.; Andrus, M.B.; Anderson, T.; Miller, J.; Simmons, B.; Weddoups, G.; Moore, M. S.; Swan, R.; Allen, R.; Bodily, G. (2005). The virtual chemlab project: A realistic and sophisticated simulation of organic synthesis and organic qualitative analysis. Journal of Chemical Education, 82, 11, 1728-1735. 